\title{
粘弾性地山の応力緩和による円形トンネルの覆工土圧 \\ EARTH PRESSURE ON CIRCULAR TUNNEL LINING DUE TO STRESS RELAXATION IN VISCO-ELASTIC GROUND
}

\author{
村 山 朔 郎* - 藤 本 徹** \\ By Sakuro Murayama and Toru Fujimoto
}

\section{1. まえがき}

粘性土中にトンネルを構築する過程の中で, トンネル 開削面の動きに注目してみよう。一般に地山の開削面は 覆工が完成するまでの間は, 全く無支持のいわゆる完全 な素掘り状態か, 坑内に封入した圧縮空気圧でおさえら れるか,あるいはある間隔に建てた支保工で支持される。 支保工を設置する場合でも, 設置前にはいくらかの無支 持ないし不完全な支持期間があり，また支保工設置後で も地山の露出部や薄い矢板で覆れた部分などがあるため 開削面はかなり動きやすい。シールド工法の場合では, シールド推進後露出した開削面は覆工背面の空げき充填 が完了するまでは常圧または圧気下で素掘り状態にあ る。このようにトンネル開削面は覆工完了までは, 無支 持ないし不完全な支持状態におかれるので, その間粘性 土地山はクリープ変形をして開削面はトンネルの内方に 向って流動する。ついで覆工が設置され，その背面空げ きの充填が完了すると開削面の流動がとめられるので, 地山の変位も抑制される結果, 地山の土には応力緩和が 生じ, 覆工には地山の応力緩和による土圧が発生する。

覆工に生ずる土圧すなわち覆工土圧の様相は, トンネ ル開削によってトンネル周囲の地山に粘土の上限降伏值 を超過するせん断応力が発生するかどうか, したがって 地山に塑性領域が発生するかどうかでも異なるが，ここ では塑性領域の発生しない場合のみを扱うこととする。 また覆工土圧は, トンネル開削によって地山中に発生す る平均有効主応力が地山粘土の先行圧密応力より大きく なるか小さくなるか, すなわち地山に脱水圧密か吸水膨 張が生ずるかどうかによっても影響をうける。

粘土地山の応力緩和に基因するトンネル土圧について は，いままでいくらかの研究 ${ }^{1)}$ があるが，それらの多く

* 正会員 工博 京都大学教授 防災研究所

** 正会員 工修 京都大学防災研究所受託研究員
は掘削過程中に素掘り時のクリープ現象の存在すること を無視しているか, 粘土のレオロジー特性に実際と若干 合致しない力学特性を用いているようである。実際のト ンネルでは覆工設置までにクリープ過程が現実に存在す るために, 覆工土圧は覆工を掘削直後に設置するのに比 してかなり減少しているはずである。ゆえにここでは粘 弾性特性をもつ地山中にトンネルを構築する場合, 掘削 過程中の開削面の状況変化を考慮して, 素掘り期間の存 在, 坑内圧気圧の加除, 覆工の剛度などに実際的な施工 条件を導入して地山の応力緩和に基づく覆工土圧を解析 することとした。

ここで用いた条件と概要は,

（1）地山は Dilatancy のない一様な粘弾性体とす る。通常の粘土のせん断ひずみ特性は粘土に加えられる せん断応力だけでなく, そこの平均有効主応力の大きさ によっても支配されるが，ここでは地山中に生じる平均 主応力の変動 $\sigma_{m}$ は小さいとして $\sigma_{m}$ のせん断ひずみに

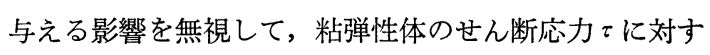
るレオロジー的挙動は粘土骨格に rate-process を適用し て誘導された図一1 の力学モデル ${ }^{2)}$ で示されるものとし た。ここに spring $G_{1}, G_{2}$ はせん断弾性係数, slider $\tau_{0}$ は下限降伏值に等しい内部摩擦抵抗で, いずれも粘弾性 体に圧密や破壊が生じないときは一定值である。 $\eta_{2}$ は 次式で示す非ニュートン粘性をもつ dash-pot である。

$$
\eta_{2}=\frac{\tau_{2}}{2 A_{2} \cdot \tau_{20} \cdot \sinh \left(B_{2} \tau_{2} / \tau_{20}\right)}
$$

ここに, $A_{2}, B_{2}$ はレオロジ一定数で圧密や破壊のない ときは応力・ひずみには無関係である。また $\tau_{2}, \tau_{20}$ は それぞれ dash-pot にかかる荷重およびその初期值であ る。この力学モデルを用いて粘土のクリープや応力緩和 の挙動はすでに解かれているが ${ }^{2)}$, ここでは粘土を一定 期間クリープさせた後, そのままの変形にとめて応力緩 和過程に移行させたときの挙動を新たに解明することと した。 
（2）覆工土圧の 基本的な関係をみる 目的で, 主として村 山はまず等方圧をう けている粘弾性地山 に半径 $a$ の円形トン ネルを構筑する場合 を扱った。ここでは， 掘削証素掘りで進 め, あたかも圧気シ

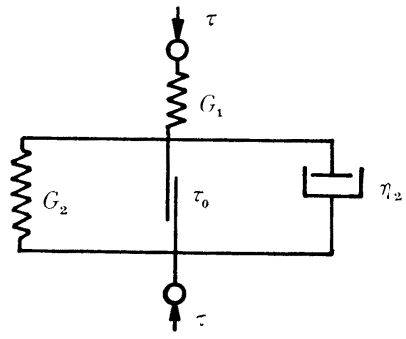

図一1 粘土の力学モデ
ールド工法のように, 開削後 $t_{c}$ 時間の間は開削面には 支保工を設置せず，坑内に湧水防止の目的で入れた圧縮 空気の圧力によって内面からおさえるのみとし, 開削面 のクリープを許すこととした。 $t_{c}$ 時間後に圧気中で一様 な厚さの弾性リングの覆工を地山開削面に密着するよう 設置し，設置完了と同時に圧気を除去して坑内を常圧に 復することとする。その後は地山の変形が抑制されるた め応力緩和による覆工土圧が発生し経時増加する。

（3）さらに実際の条件に近ゔけるため, 重力の場に ある水平表面をもつ半無限粘弾性地山中のあまり浅くな いところに円形トンネルを常圧下で掘削した場合につい て前項と同様の方針で解析した。

\section{2. クリープ後に応力緩和過程に移行した粘土 の挙動}

\section{（1） カ学モデル}

半無限粘弾性地山中に円形トンネルを開削した場合, トンネル開削のために地山に発生するせん断応力が粘土 の上限降伏值以下のときは地山のクリープ変形や応力緩 和に基づくトンネルの変形や覆工土圧の経時変化は前述 の図一1 の力学モデルを用いで解析することができる。 そのためまずこの力学モデルの特性と挙動について述べ る。

一般の粘土においては図一1 の力学モデル中のスライ ダー要素 $\tau_{0}$ の值は $G_{2}, \eta_{2}$ 加生ずる変形抵抗にくらべ てきわめて小さいから，ここではこれを無視して， $G_{1}$, $G_{2}, \eta_{2}$ からなる 3 要素モデルを用いる。この 3 要素力学 モデルの全体のせん断ひずみを $r$, 独立スプリング $G_{1}$ のひずみを $r_{1}, G_{2}$ と $\eta_{2}$ からなる modified Voigt 要 素のひずみを $\gamma_{2}$ とする。また式 (1) 中, $B_{2} \cdot \tau_{2} / \tau_{20}$ が次 の式 $(2)$ の範囲では $2 \sinh \left(B_{2} \tau_{2} / \tau_{20}\right) \doteqdot \exp \left(B_{2} \tau_{2} / \tau_{20}\right)$ と 近似することができる。

$$
B_{2} \tau_{2} / \tau_{20} \geq 2
$$

ゆえに式 (2) の範囲では, この力学モデルの時間 $t$ 亿関 する挙動は次式によって表わされる。

$$
\left.\begin{array}{l}
r=\gamma_{1}+r_{2}, \quad r_{1}=\tau / G_{1}, \\
\frac{d \gamma_{2}}{d t}=A_{2} \cdot \tau_{20} \cdot \exp \left(B_{2} \frac{\tau_{2}}{\tau_{20}}\right), \tau_{2}=\tau-G_{2} \cdot \gamma_{2}
\end{array}\right\}
$$

$\tau_{2}$ が式 (2) の範囲を越え， $B_{2} \tau_{2}<2 \tau_{20}$ となり，かつ 十分に時間が経過すると， $\tau_{2} \rightarrow 0$ となるから， $r$ は次式 の $r_{\infty}$ に限りなく近づく。

$$
(\gamma)_{t \rightarrow \infty}=\left(\frac{1}{G_{1}}+\frac{1}{G_{2}}\right) \cdot \tau \equiv r_{\infty}
$$

\section{（2）クリープ特性 ${ }^{2)}$}

変形が安定しているいわゆる新鮮な粘土に一定のせん 断応力 $\tau$ を与えたときの正常クリープは式 (2)，(3), (4) を $\tau$ 一定の条件で解いたときの $r$ と $t$ の関係で与 えられる。式 (2) の条件はrに対しては次式で示され る。

$$
\frac{\tau}{G_{1}}+\left(B_{2}-2\right) \frac{\tau}{B_{2} G_{2}} \equiv r_{b} \geq r
$$

$r$ が上式の上うに $r \leq r_{b}$ であれば式 (3) の解は,

$$
r=\left\{\frac{1}{G_{1}}+\frac{1}{G_{2}}+\frac{1}{B_{2} G_{2}} \log \left(A_{2} \cdot B_{2} \cdot G_{2} \cdot t\right)\right\} \cdot \tau
$$

また, $r>r_{b}$ の範囲でしかも $t \rightarrow \infty$ になると, $r$ は式 (4)のように $r \rightarrow \gamma_{\infty}$ となる。すなわちひずみ $r$ は図一 2 (a) の実線のように $r_{b}$ までは式 (6) の示すように $\log t$ に比例して増加し, その後 $r$ の増加速度は漸次減 少しついに停止して $r_{\infty}$ となる。

このようなひずみの経時変化を粘土のみかけせん断弾 性係数の変化で示すと, クリープ中の弾性係数を $G_{c}$, $t \rightarrow \infty$ において到達する $G_{c}$ の值を $G_{\infty}$ とすれば,

$$
\gamma=\tau / G_{c}, r_{\infty}=\tau / G_{\infty}, 1 / G_{\infty}=\left(1 / G_{1}\right)+\left(1 / G_{2}\right)
$$

$\gamma$ と $r_{\infty}$ の関係は式 $(4),(6),(7)$ を比較して, $r=\left(G_{\infty} / G_{c}\right) r_{\infty}=(a+b \log t) r_{\infty} \equiv \phi(t) \cdot r_{\infty}$ ここに, $\phi(t)=a+b \cdot \log t\left(\langle 1),[\phi(t)]_{t \rightarrow \infty}=1\right.$,

$$
\begin{aligned}
& a=\left\{\frac{1}{G_{1}}+\frac{1}{G_{2}}+\frac{1}{B_{2} G_{2}} \log \left(A_{2} \cdot B_{2} \cdot G_{2}\right)\right\} G_{\infty}, \\
& b=\frac{1}{B_{2} \cdot G_{2}} G_{\infty} \\
& \therefore \quad G_{c}=\frac{G_{\infty}}{\phi(t)}, G_{\infty}=\frac{G_{1} \cdot G_{2}}{G_{1}+G_{2}} \ldots \ldots \ldots \ldots \ldots(9)
\end{aligned}
$$

\section{（3） 応力緩和特性 ${ }^{2)}$}

新鮮な粘土に一定ひずみ $r_{0}$ を与えてそのひずみに拘 束したとき，拘束応力の緩和特性はひずみ $\gamma$ 一定（すな わち $\left.r=r_{1}+r_{2}=r_{0}\right)$ の条件で式 (3)，(4) を解いて求め られる。式 (2)の条件はてに対しては次式で示される。 


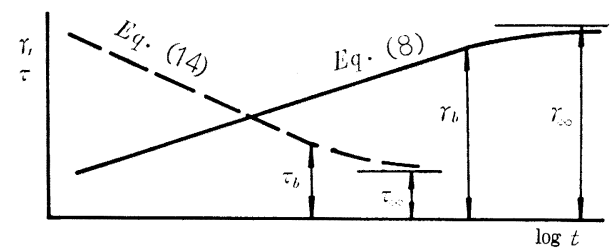

図一2（a）粘土のクリープと応力緩和曲線

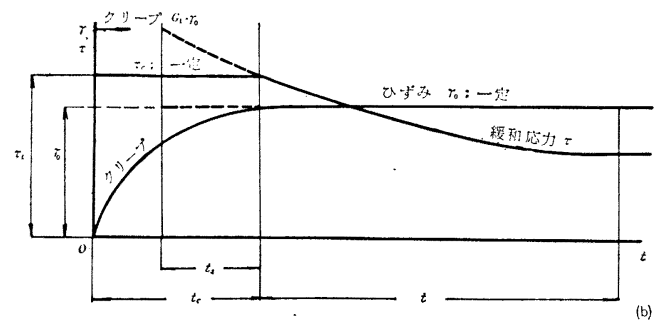

図一2（b） クリープ過程後の応力緩和曲線

$$
\frac{G_{1} \cdot G_{2}}{G_{1}+G_{2}}\left(1+\frac{2 G_{1}}{B_{2} \cdot G_{2}}\right) r_{0}\left(\equiv \tau_{b}\right) \leq \tau
$$

上式の範囲では緩和応力 $\tau$ は式 $(3)$ より次のようになる。

$$
\tau=\frac{G_{1} \cdot G_{2}}{G_{1}+G_{2}}\left[1-\frac{G_{1}}{B_{2} \cdot G_{2}} \log \left\{A_{2} \cdot B_{2}\left(G_{1}+G_{2}\right) t\right\}\right] \gamma_{0}
$$

$\tau$ が式 (10) の $\tau_{b}$ 以下に減少し, かつ $t \rightarrow \infty$ では,

$$
(\tau)_{t \rightarrow \infty}=\frac{G_{1} \cdot G_{2}}{G_{1}+G_{2}} r_{0} \equiv \tau_{\infty}
$$

すなわち拘束応力 $\tau$ は図一2 (a) の点線のように $\tau_{b}$ ま では $\log t$ に比例して減少し, その後 $\tau$ の減少速度は漸 次低下しついに停止して $\tau_{\infty}$ となる。

新鮮な粘土の弾性係数は応力緩和の初期 $(t=0)$ では $G_{1}$ であるが, 応力緩和中は式(11)より求められる $\left(\tau / r_{0}\right)$ $\left(\tau / r_{0}=G_{r}\right.$ と記す) で示され, $t \rightarrow \infty$ の終局時には式(12) が示すようにクリープ過程の終局值 $G_{\infty}$ と同值になる。 すなわち，

$$
\tau=G_{r} \cdot r_{0}, \quad \tau_{\infty}=G_{\infty} \cdot r_{0}
$$

$\tau$ と $\tau_{\infty}$ の関係は式 (11), (12), (13) を比較して, $\tau=\left(G_{r} / G_{\infty}\right) \tau_{\infty}=\left(a^{\prime}-b^{\prime} \log t\right) \tau_{\infty} \equiv \psi(t) \cdot \tau_{\infty}$ ここに, $\psi(t)=a^{\prime}-b^{\prime} \log t(\geq 1),[\psi(t)]_{t \rightarrow \infty}=1$,

$$
\begin{aligned}
& a^{\prime}=1-\frac{G_{1}}{B_{2} \cdot G_{2}} \log \left\{A_{2} \cdot B_{2}\left(G_{1}+G_{2}\right)\right\}, \\
& b^{\prime}=\frac{G_{1}}{B_{2} \cdot G_{2}}
\end{aligned}
$$

$$
\therefore G_{r}=\psi(t) \cdot G_{\infty}, \quad G_{\infty}=\frac{G_{1} \cdot G_{2}}{G_{1}+G_{2}}
$$

\section{（4） クリープ過程後の応力緩和特性}

粘土をある期間クリープさせた後, 応力緩和過程に移 行させたときの挙動は今まで解かれていないのでまずそ
の解析を行ならこととする。

いま新鮮な粘土試料を $\tau_{c}$ の一定応力のもとで $t_{c}$ 時 間クリープをさせてひずみが $r_{0}$ に達したとき, それ以 上変形が増大しないようひずみを $r_{0}$ に拘束固定して応 力緩和過程に移行させると, 拘束応力 $\tau$ は移行当初は $\tau_{c}$ であるがしだいに小さくなっていく。

式 $(7)$, (8) より $t_{c}$ 時間のクリープ過程後の $r_{0}$ を表 わすと,

$$
r_{0}=\left(a+b \cdot \log t_{c}\right) \cdot\left(\tau_{c} / G_{\infty}\right) \equiv\left(\tau_{c} / G_{\infty}\right) \cdot \phi\left(t_{c}\right)
$$

なお応力緩和過程に移行した時点の modified Voigt 要 素のひずみを $r_{20}$ とすると, $r_{20}(>0)$ は次式から求め られる。

$$
\tau_{c}=\left(r_{0}-r_{20}\right) \cdot G_{1}
$$

一方上記とは別に, ごの新鮮粘土試料をクリープさせ ることなく新鮮なままで初期ひずみ $r_{0}$ を与えて応力緩 和を行なら場合を考える。この場合の初期応力は $G_{1} \cdot r_{0}$

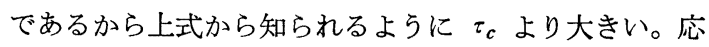
力緩和をつづけ拘束応力が減少して $\tau_{c}$ に等しくなると きまでの経過時間を $t_{s}$ とすれば，この関係は式 (13)， (14)より

$$
\tau_{c}=\left\{a^{\prime}-b^{\prime} \log t_{s}\right\} \cdot G_{\infty} \cdot \gamma_{0} \equiv G_{\infty} \cdot \gamma_{0} \cdot \psi\left(t_{s}\right)
$$

その後もそのままのひずみに拘束してさらに応力緩和を つづけ， $t_{s}$ 時間後さらに $t$ 時間が経過したときの緩和 応力 $\tau$ の值は, この新鮮粘土試料に初期ひずみ $\gamma_{0}$ を与 えて $\left(t_{s}+t\right)$ 時間応力緩和を行なったときの関係である から，上式と同様にして，

$$
\tau=\left\{a^{\prime}-b^{\prime} \log \left(t_{s}+t\right)\right\} G_{\infty} \cdot r_{0}=G_{\infty} \cdot r_{0} \cdot \psi\left(t_{s}+t\right)
$$

前述したように, 上限降伏值以下の応力範囲ではクリ 一プや応力緩和によってレオロジ一定数には変化が生じ ないから, 式 (16)，(17)，(18）に含まれるレオロジー 定数は同一である。ゆえに式 (16) の $\tau_{c}$ に式 (17) を 代入すると次式のように $t_{c}$ とそれに対応する $t_{s}$ との関 係が求められる。

$$
\left.\begin{array}{c}
\left(a+b \log t_{c}\right) \cdot\left(a^{\prime}-b^{\prime} \log t_{s}\right)=1 \\
ち, \quad \phi\left(t_{c}\right) \cdot \psi\left(t_{s}\right)=1
\end{array}\right\}
$$

ゆえに図一2 (b) のように新鮮粘土をまず $\tau_{c}$ の応力 のもとで $t_{c}$ 時間クリープさせひずみが $\gamma_{0}$ に達したと き，ついでそのひずみのもとで応力緩和に移行させ，移 行後 $t$ 時間経過したときの粘土の応力は, この粘土を最 初にクリープさせることなく, 新鮮なまま上記の移行時 刻より $t_{s}$ 時間以前の時刻に初期ひずみ $r_{0}$ を与えて, そ のままのひずみで応力緩和を行ない, 合計 $\left(t_{s}+t\right)$ 時間 を経過したときの緩和応力に等しいこととなる。後者の 過程の場合, $\left(t_{s}+t\right)$ 時刻における緩和応力は式 (18) 
によって示され，またこの時点のみかけの弾性係数 $G_{s}$ は, 式 (18)，(13) より次のように求められる。

$G_{s}=\tau / r_{0}=\psi\left(t_{s}+t\right) \cdot G_{\infty},\left(G_{s}\right)_{t \rightarrow \infty}=G_{\infty} \cdots$

\section{（5）地山粘土の応カ・ひずみ挙動}

粘性土中にトンネルを開削したとき開削によって地山 中に発生する応力が粘土の先行圧密応力と大差なくかつ 上限降伏值を超過しないときは, 粘土には圧密, 膨張や 破壊は生じない。この場合には地山粘土のレオロジ一定 数は前述のように応力・ひずみの大きさに無関係である から地山がクリープ過程にある場合も応力緩和過程にあ る場合も地山のみかけ弾性係数やその time factor $\phi(t)$, $\psi(t)$ もまた応力・ひずみに無関係であって時間だけの関 数となる。

また半無限弾性地山中に円形トンネルを素掘りで開削 した場合は，地山中の各点の応力の值は開削面の微小な 変形を無視するならば，変形と無関係に決定できる。し たがって半無限粘弾性地山がトンネルの素掘り状態のも とでクリープをしている間の地山各点の応力の值には時 間的変動がなく一定值であるとみられる。また同様に半 無限粘弹性地山が覆工施工後応力緩和をしている間は覆 工のわずかの変形量の変動が地山各点の変位におよぼす 影響を無視するならば地山各点のひずみの值には時間的 変動がないとみられる。

ゆえにトンネル周囲の地盤のクリープや応力緩和挙動 は, 地山が一定な弾性定数 (せん断弾性係数 $G_{\infty}$, ポア ソン比 レ) を持つ弾性体として弾性力学的に解析し, 得 られた結果のひずみや応力の式に含まれる弾性係数 $G_{\infty}$ に time factor を乗ずることによって求められる。

\section{3. 等方圧をうける粘弾性体中のトンネル土圧}

\section{（1） 半無限弾性体中の円形トンネル}

半無限粘弾性体を扱らに先立ち半無限弾性体について 考察する。いま水平地表面をもつ半無限の弾性地山中に 円形トンネルを水平に開削する場合を想定し，トンネル 軸を $z$ 軸に, $r, \theta$ 軸を 図一4 右半のようにとる。この 軸に関し，トンネル開削前に地山中の一点が自重などの ために受けていた圧力を $\sigma_{r 0}, \sigma_{\theta 0}, \sigma_{z 0}$ (ただし軸の負の 方向に向う圧力を正とする),この応力による初期圧縮ひ ずみを $\varepsilon_{r 0}, \varepsilon_{\theta 0}, \varepsilon_{z 0}$ とする。またトンネル開削後，すな わち素掘り期間中または覆工施工後に地山中のこの点に おける $r, \theta, z$ 方向の圧力をそれぞれ $\sigma_{r}, \sigma_{\theta}, \sigma_{z}$ とし， この点の圧縮ひずみが開削後に開削前の初期ひずみ以上 に増加した量を $\varepsilon_{r}, \varepsilon_{\theta}, \varepsilon_{z}$ とする。

地山のヤング俰数を $E$, ポアソン比を $\nu$, せん断弹性
係数を $G(G=E /\{2(1+\nu)\})$ とすれば, 開削前の応力と ひずみの関倸は,

$$
\begin{aligned}
& \varepsilon_{r 0}=\left\{\sigma_{r 0}-\nu\left(\sigma_{\theta 0}+\sigma_{z 0}\right)\right\} / E \\
& \varepsilon_{\theta 0}=\left\{\sigma_{\theta 0}-\nu\left(\sigma_{r 0}+\sigma_{z 0}\right)\right\} / E \\
& \varepsilon_{z 0}=\left\{\sigma_{z 0}-\nu\left(\sigma_{r 0}+\sigma_{\theta 0}\right)\right\} / E
\end{aligned}
$$

上式より $\sigma_{z 0}$ および $E$ を消去して $\varepsilon_{r 0}, \varepsilon_{\theta 0}$ を求めると

$$
\left.\begin{array}{l}
\varepsilon_{r 0}=\left\{(1-\nu) \sigma_{r 0}-\nu \sigma_{\theta 0}\right\} /(2 G)-\nu \varepsilon_{z 0} \\
\varepsilon_{\theta 0}=\left\{(1-\nu) \sigma_{\theta 0}-\nu \sigma_{r 0}\right\} /(2 G)-\nu \varepsilon_{z 0} \\
\sigma_{z 0}=\nu\left(\sigma_{r 0}+\sigma_{\theta 0}\right)+E \cdot \varepsilon_{z 0}
\end{array}\right\}
$$

次にトンネル開削後の地山の応力とひずみの関保は,

$$
\begin{aligned}
& \varepsilon_{r 0}+\varepsilon_{r}=\left\{\sigma_{r}-\nu\left(\sigma_{\theta}+\sigma_{z}\right)\right\} / E \\
& \varepsilon_{\theta_{0}}+\varepsilon_{\theta}=\left\{\sigma_{\theta}-\nu\left(\sigma_{r}+\sigma_{z}\right)\right\} / E \\
& \varepsilon_{z 0}+\varepsilon_{z}=\left\{\sigma_{z}-\nu\left(\sigma_{r}+\sigma_{\theta}\right)\right\} / E
\end{aligned}
$$

トンネル開削後, 地山は $z$ 軸に関して平面ひずみ状態を 保持すると仮定すると, $\varepsilon_{z}=0$ となるから, 上式より

$$
\left.\begin{array}{l}
\varepsilon_{r}=\left\{(1-\nu) \sigma_{r}-\nu \sigma_{\theta}\right\} /(2 G)-\left(\varepsilon_{r 0}+\nu \varepsilon_{z 0}\right) \\
\varepsilon_{\theta}=\left\{(1-\nu) \sigma_{\theta}-\nu \sigma_{r}\right\} /(2 G)-\left(\varepsilon_{\theta 0}+\nu \varepsilon_{z 0}\right) \\
\sigma_{z}=\nu\left(\sigma_{r}+\sigma_{\theta}\right)+E \cdot \varepsilon_{z 0}, \quad \varepsilon_{z}=0
\end{array}\right\}
$$

式 (21), (22) 上り,

$$
\left.\begin{array}{l}
\varepsilon_{r}=\left\{(1-\nu)\left(\sigma_{r}-\sigma_{r 0}\right)-\nu\left(\sigma_{\theta}-\sigma_{\theta 0}\right)\right\} /(2 G) \\
\varepsilon_{\theta}=\left\{(1-\nu)\left(\sigma_{\theta}-\sigma_{\theta 0}\right)-\nu\left(\sigma_{r}-\sigma_{r 0}\right)\right\} /(2 G) \\
\sigma_{z}-\sigma_{z 0}=\nu\left(\sigma_{r}-\sigma_{r 0}\right)+\nu\left(\sigma_{\theta}-\sigma_{\theta 0}\right)
\end{array}\right\} .
$$

式 (23) 第 1,2式の意味するところは平面ひずみの条件 を入れ，地山を 2 次元の弾性体として扱っている以上当 然のことであるが，トンネルを開削したために生ずる地 山のひずみの増分は, 開削のために生ずる地山の 2 次元 的な応力増分と一次の関倸にあり，初期ひずみの值には 無関係である。しかしこのようなひずみの増分を開削後 の地山応力 $\sigma_{r}, \sigma_{\theta}$ だけで表わすと, 式 (22) で示すよう に $\varepsilon_{r 0}, \varepsilon_{\theta 0}$ だけでなく, $z$ 方向の初期ひずみ $\varepsilon_{z 0}$ も関与 することになる。したがって式 (23) を用いればトンネ ル開削にともならひずみの変化は，次にのべるような初 期等方ひずみのある場合にも， 4. にのべるような水平 表面をもつ半無限弾性体が深さ方向に平面ひずみ状態を 保って一次元的に自重で圧縮された場合にも適用するこ とができる。

\section{（2）等方圧をうける弾性体中のトンネル}

トンネルの径に比して土かぶりがかなり大きく, 地山 の側方土圧倸数をかりに 1 と仮定すれば，トンネル周囲 の地山の応力状態は地山の自重のかわりに土かぶりに相 当する初期応力 $\sigma_{0}$ を等方作用させた状態として扱っ ても大差がない。地山の単位体積重量を $r_{s}$, トンネル中 心以上の土かぶりを $H$ とすれば, $\sigma_{0}=\gamma_{s} \cdot H$ である。

すなわちトンネル開削前の地山の初期応力は,

$$
\sigma_{r 0}=\sigma_{\theta 0}=\sigma_{z 0}=\sigma_{0}=\gamma_{s} \cdot H \cdots \cdots \cdots \cdots \cdots \cdots \cdots \cdots \cdots \cdots \cdots \cdots(24)
$$

ゆえに初期ひずみも等方に生じ，上式と式 (21) よ》， 


$$
\varepsilon_{r 0}=\varepsilon_{\theta 0}=\varepsilon_{z 0}=\varepsilon_{0}=\{(1-2 \nu) /(1+\nu)\} \cdot\left\{\sigma_{0} /(2 G)\right\}
$$

またトンネルが円形で初期応力と初期ひずみが等方であ るときは, トンネル開削後（素掘り期間中または覆工完 成後) のトンネル横断面内の地山応力とひずみはともに $z$ 軸に関し軸対称となる。

上述のような，均等な外圧をうける弾性体の円孔のま わりの応力はすでに次のように与えられている。

$$
\sigma_{r}=\alpha_{1}-\alpha_{2} / r^{2}, \quad \sigma_{\theta}=\alpha_{1}+\alpha_{2} / r^{2}
$$

ここに， $\alpha_{1}, \alpha_{2}$ は境界条件できまる定数。

均等な外圧をうける場合， $\sigma_{r}$ の方向 (トンネル中心に 向う方向）にはかった地山の変位を $u$ とすれば， $u$ は，

$$
\varepsilon_{r}=d u / d r, u=r \cdot \varepsilon_{\theta} .
$$

汸えにトンネル開削面 (半径：a) に扔ける地山の開削 後の変位量 $u_{a}$ は式 (27) 第 2 式に式 (23) 第 2 式を代 入し, $r=a$ とおけば

$$
u_{a}=a \cdot\left\{(1-\nu)\left(\sigma_{\theta}-\sigma_{\theta 0}\right)-\nu\left(\sigma_{r}-\sigma_{r 0}\right)\right\}_{r=a} /(2 G)
$$

a） 素掘り期間中の地山の応力と変形

素掘り期間中は坑内に圧縮空気を封入するものとす る。圧気圧が地山を実質的におす有効圧力は土質や加圧 時間で異なるが，ここでは圧気の有効圧力を一定值 $\sigma_{a}$ とする。境界条件はトンネル内面 $(r=a)$ では $\sigma_{r}=\sigma_{a}$, またトンネルから十分遠方 $(r \rightarrow \infty)$ では $\sigma_{r}=\sigma_{\theta}=\sigma_{0}$ と おけるから，これらの条件を式 (26) 代代入すると，

$$
\sigma_{r}=\sigma_{0}-\left(\sigma_{0}-\sigma_{a}\right)(a / r)^{2}, \sigma_{\theta}=\sigma_{0}+\left(\sigma_{0}-\sigma_{a}\right)(a / r)^{2}
$$

素掘りトンネルの開削面が開削後トンネル内方に変位 する量を $u_{a c}$ とすれば， $u_{a c}$ は式 (24)，(29）を式 (28) 汇代入して

$$
u_{a c}=\frac{\sigma_{0}-\sigma_{a}}{2 G} \cdot a
$$

\section{b) 覆工構筑後の地山の応力と変形}

覆工 (外周面半径： $a$ ) は圧気中で, 地山を㧍しつけ ないがすき間ができないように構築し, 構築完了後ただ ちに圧気を常圧にもどし, それ以後は圧気を適用しない ものと仮定する。圧気除圧後の覆工と地山との接触圧を $p$ とすれば, 式 (26) に対する境界条件は, $r=a$ にお いて $\sigma_{r}=p, r \rightarrow \infty$ に拈いて $\sigma_{r}=\sigma_{\theta}=\sigma_{0}$ であるから，

$$
\sigma_{r}=\sigma_{0}-\left(\sigma_{0}-p\right) \cdot(a / r)^{2}, \sigma_{\theta}=\sigma_{0}+\left(\sigma_{0}-p\right) \cdot(a / r)^{2}
$$

覆工構築後の開削面の開削前の位置からの変位量 $u_{a s}$ 虹式 (28), (31) より

$$
u_{a s}=\frac{\sigma_{0}-p}{2 G} \cdot a
$$

上記 a), b) の場合について, 地山中の $z$ 方向の応力 と平均主応力がトンネル開削によってらける変化を調べ
よう。トンネル開削後の地山の平均主応力が開削前の值 よりも増加した量を $\sigma_{m}$ とする。 $\sigma_{m}$ は,

$$
\sigma_{m}=\left\{\left(\sigma_{r}-\sigma_{r 0}\right)+\left(\sigma_{\theta}-\sigma_{\theta 0}\right)+\left(\sigma_{z}-\sigma_{z 0}\right)\right\} / 3
$$

式 (23) の第 3 式, 式 (24) と上式および式 (29) また は式 $(31)$ を用いて， $\sigma_{z}$ と $\sigma_{z 0}$ の関係および $\sigma_{m}$ を求 めると，

$$
\sigma_{z}=\sigma_{z 0}=\sigma_{0}, \quad \sigma_{m}=0 .
$$

このように初期等方圧力をうけている弾性体中にトンネ ルを開削し，開削後トンネル軸方向に平面ひずみ状態が 保たれている場合には平均主応力には増減が生じないか ら, 弾性体地山には体積ひずみは発生せず，トンネル開 削面の変形はすべて弾性体地山のせん断変形のみに起因 することが知られる。

\section{（3） 外圧 $\boldsymbol{p}$ をうける覆工の応力・ひずみ}

覆工は外径 $a$, 内径 $b$ の円形弾性環（図一4 参照）と し, 外周は 地山に密着して地山より均等な圧力 $p$ をう け, 内面は無支持とする。覆工の自重を無視すれば覆工 内の応力 $\sigma_{r l}, \sigma_{\theta l}$ (添字 $l$ は覆工の意) は式 (26) に上 記の境界条件を入れて求められる。すなわち, $r=a$ で は $\sigma_{r l}=p, r=b$ では $\sigma_{r l}=0$ であるから, $b<r<a$ の範囲では,

$$
\left.\begin{array}{rl}
\sigma_{r l} & =\frac{a^{2} \cdot b^{2}}{a^{2}-b^{2}}\left(\frac{1}{b^{2}}-\frac{1}{r^{2}}\right) \cdot p \\
\sigma_{\theta l} & =\frac{a^{2} \cdot b^{2}}{a^{2}-b^{2}}\left(\frac{1}{b^{2}}+\frac{1}{r^{2}}\right) \cdot p
\end{array}\right\} .
$$

覆工は無応力の状態で建設され, 応力 $p$ をうけたとき $z$ 軸に対して平面ひずみ状態にあるとすれば, $z$ 方向の 応力 $\sigma_{z l}$ と $\sigma_{r l}, \sigma_{\theta l}$ との関係は,

$$
\sigma_{z l}=\nu_{l}\left(\sigma_{r l}+\sigma_{\theta l}\right)
$$

沛えに, $r, \theta$ 方向のひずみ $\varepsilon_{r l}, \varepsilon_{\theta l}$ を求めると,

$$
\begin{aligned}
\varepsilon_{r l} & =\left\{\sigma_{r l}-\nu_{l}\left(\sigma_{\theta l}+\sigma_{z l}\right)\right\} / E_{l} \\
& =\left\{\left(1-\nu_{l}\right) \sigma_{r l}-\nu_{l} \cdot \sigma_{\theta l}\right\} /\left(2 G_{l}\right) \\
\varepsilon_{\theta l} & =\left\{\left(1-\nu_{l}\right) \sigma_{\theta l}-\nu_{l} \cdot \sigma_{r l}\right\} /\left(2 G_{l}\right), \\
E_{l} & =2\left(1+\nu_{l}\right) \cdot G_{l}
\end{aligned}
$$

ここに, $E_{l}, \nu_{l}$ および $G_{l}$ はそれぞれ覆工材料の弾性係 数, ポアソン比およびせん断弾性係数である。

また覆工外周面がトンネル中心方向に向ら変位量 $u_{l}$ は式 (27) に式 (35) の $\varepsilon_{\theta l}$ と式 (34) を代入して

$$
u_{l}=\left[r \cdot \varepsilon_{\theta l}\right]_{r=a}=\frac{\left(1-2 \nu_{l}\right) a^{2}+b^{2}}{2 G_{l}\left(a^{2}-b^{2}\right)} \cdot a \cdot p
$$

\section{（4）素掘りトンネルにおける開削面のクリープ変形}

式 (30) において $\sigma_{a}$ は間げき水圧に対抗するために 坑内に封入した圧縮空気圧より生ずる応力であるから, 帯水層の被圧水頭が地表以上かなり高くない限り通常 $\sigma_{a}$ はトンネルの上載荷重圧 $\sigma_{0}$ に比して小さい。ゆえに式 (30)より, $u_{a c}>0$ となり, 地山が粘弾性体からできて 
いる場合には開削面は素掘り期間中トンネル内方に向っ てクリープ変形をする。クリープをおこす地山内のせん 断応力は $\sigma_{\theta}-\sigma_{r}$ であって, この值は $a$ の微少な変化を 無視すれば式 (29) からわかるようにクリープ中つねに 一定である。ここでは地山のせん断応力は粘土の上限降 伏值を超過しない場合を扱らものとする。式 (30) の $G$ は弾性体に対するものであったが, 粘弾性体ではみかけ の $G$ はクリープ時間とともに式 $(9)$ の $G_{c}$ で示されるよ らに減少し, $t \rightarrow \infty$ では $G_{\infty}$ となる。 $G_{c}, G_{\infty}$ は応力や ひずみの大きさには無関係であるから, トンネル開削の 場合, 地山中の位置 $(r, \theta)$ にも無関係でただ時間 $t$ の みの関数となり, それぞれの点において式 (8)のクリー プひずみが生じる。

ゆえにいま, $\sigma_{0}$ の初期応力のある粘弾性地山に半径 $a$ の円形トンネルを有効圧気圧 $\sigma_{a}$ を用いて素掘り掘削し たとき, 開削後 $t_{c}$ 時間後のトンネル開削面の内方移動 量 $u_{c}$ は式 (30) の $G$ に $G_{c}\left(=G_{\infty} / \phi(t)\right)$ を代入して次 のよらに求められる。

$$
\left.\begin{array}{ll}
u_{c}=\left(\sigma_{0}-\sigma_{a}\right) \cdot a \cdot \phi\left(t_{c}\right) / 2 G_{\infty}, \\
\text { こに } \quad \phi\left(t_{c}\right)=a+b \cdot \log t_{c}
\end{array}\right\}
$$

上述のようなトンネル開削面の移動が経過時間の対数 に比例している例は実際のトンネルにおいてしばしば測 定されており，これらの変形がここにのベたクリープ特 性によって説明できる場合がきわめて多いと思われる。

\section{（5）施工に伴う開削面の変位の推移}

トンネル開削面の変位は地山のひずみの総合されたも のといえよう。地山のひずみ挙動は図一1 の力学モデル （ただし $\tau_{0}$ は除く）で代表できるから，施工に伴ら開 削面の変位の推移もこのような 3 要素力学モデルの変位 にある一定倍率を乗じたものとして示すことができる。

各施工過程における開削面の変位の推移をこのような 3 要素モデルを用いて模式的に示すと図一3 (a)〜 (e) と なる3)。なお 図一3 (f) は, 地山の挙動を示す力学モデ

$\begin{array}{lllll}(a) & (b) & (c) & (d) & (e)\end{array}$

開削前 素堀期間 覆工期間

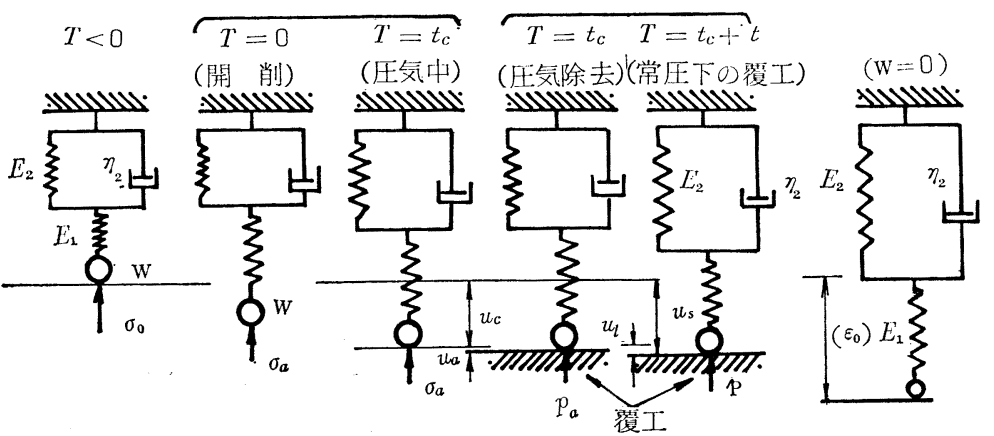

図一3 施エに伴う力学モデルの变化 (f) 無拘束状態

ルで，無載荷時の状態を示し，したがってばね $E_{1}, E_{2}$ は完全に伸長している。

地山は自然堆積状態では, 地山の自重 ( $\sigma_{0}$ に相当) に よって圧縮（ $\varepsilon_{0}$ に相当）されているから，この力学モデ ルも開削前は図（a）のように圧縮された状態にある。 地山は開削と同時に坑内の圧気圧をらけるが，開削の瞬 間 $(T=0)$ にはばね $E_{1}$ が図 (b) のように伸長して, 瞬間的な弾性変形が地山に生じ, 開削面がトンネル内方 に移動する。しかし modified Voigt モデルの $E_{2}$ はこ の時刻ではまだ変化していない。困中の $W$ はこのモデ ルが分担する地山の重量, $\sigma_{a}$ は変形に抵抗する坑内圧 気圧である。図 (c) は開削後圧気をかけた素掘り状態の まま $t_{c}$ 時間クリープさせたときの状態で, $E_{1}$ の伸びは 図 (b) のときと変わらないが, $E_{2}$ が伸長している。こ のためトンネル開削面は, 図 (c) のように開削前の位置 より $u_{c}$ だけ内方にクリープ変形する。図 (d) では $T=$ $t_{c}$ の時刻に圧気中で覆工を地山に密接して構築し, 構築 完成と同時に圧気を除去したときの状態である。この圧 気の排除のため, 圧気で圧されていた地山開削面が覆工 をおし返し覆工に加圧と変形を与える。このとき生ずる 覆工と地山の接触圧を $p_{a}$, 覆工外周面の初期構築位置 よりの変位を $u_{a}$ とする。

覆工完成後さらに時がたつと図（e）のようにさらに $E_{2}$ が伸びるが, 覆工によって力学モデル全体の長さが 抑制されているので， $E_{1}$ は時とともに圧縮される。 $E_{1}$ の圧縮によって覆工に与える圧力 $p$ 増大するので, 覆 工は構築初期 $\left(T=t_{c}\right)$ の位置より $u_{l}$ だけひずむ。さ らに十分時間がたてば $(T \rightarrow \infty)$ で dash-pot $\eta_{2}$ は $\eta_{2}$ $\rightarrow 0$ となるので, この力学モデルは $E_{1}$ と $E_{2}$ を直列に 結んだものと等価となる。

トンネル掘削前の開削面に相当する位置を基準線にと ると, 図一3 (c), (e) のように, 地山が圧気に抗して $t_{c}$ 時間クリープした後の開削面の移動量はこの基準線から 測って $u_{c}$ であり，また覆工後に地山の応力緩和によっ て地山開削面が移動する量は上 記基準線から測って $u_{s}$ となる から, 覆工外周面が構築後に変 形する量 $u_{l}$ は,

$$
u_{l}=u_{s}-u_{c}
$$

\section{（6）地山の応力緩和によっ} て生ずる覆エ土圧

外圧 $p$ は応力緩和中覆工にか かる土圧でここでは未知数であ るが，剛性の大きい覆工を軟弱 地盤中に設置する場合は, $p$ に よって生ずる覆工の変形 $u_{l}$ は 
トンネル開削面のクリープ変形量 $u_{c}$ に比して非常に小 さい。ゆえに覆工完成後の地山の応力緩和過程における 地山開削面の変形量 $\left(u_{c}+u_{l}\right)$ のうち微少な $u_{l}$ を無視 すれば, 応力緩和中の地山の変形量は初期からつねに一 定値 $u_{c}$ に固定されているものとみなしても大差がない。 応力緩和中の地山のひずみが一定な場合は, 応力緩和中 の地山の弾性係数は式 (20) の $G_{s}$ で示されるから， $u_{s}$ はこの $G_{s}$ を式 (32) に代入したときの $u_{a s}$ として求め られる。

$$
\begin{aligned}
& u_{s}=\left(\sigma_{0}-p\right) \cdot a / 2 G_{s}, \\
& G_{s}=\psi\left(t_{s}+t\right) \cdot G_{\infty}, \psi\left(t_{s}+t\right)=a^{\prime}-b^{\prime} \log \left(t_{s}+t\right)
\end{aligned}
$$

式 (36) の $u_{l}$, 式 (37) の $u_{c}$ および式 (39) の $u_{s}$ を 式 (38) に代入すれば,

$$
\begin{aligned}
& \frac{\left(1-2 \nu_{l}\right) a^{2}+b^{2}}{2 G_{l} \cdot\left(a^{2}-b^{2}\right)} \cdot a \cdot p=\frac{\left(\sigma_{0}-p\right) \cdot a}{2 G_{\infty} \cdot \psi\left(t_{s}+t\right)} \\
& -\frac{\left(\sigma_{0}-\sigma_{a}\right) \cdot a \cdot \phi\left(t_{c}\right)}{2 G_{\infty}}
\end{aligned}
$$

上式を式 (19) の関係を用いて $p$ について解けば， $p$ は覆工を構築して圧気除圧ののち $t$ 時間を経過したとき の覆工土圧となる。そのうち $t=0$ における $p$ は応力緩 和過程の初期, すなわち覆工を地山に密接させて構築し たのち圧気を除いたときの, 坑内圧気の除圧に起因する 覆工士圧 $p_{a}$ (図一3 $(\mathrm{d})$ 参照)である。p, $p_{a}$ を次に示す。 $t=t$ のとき :

$$
\begin{aligned}
& t=t \text { のとき : } \\
& p=\frac{1-\frac{\psi\left(t_{s}+t\right)}{\psi\left(t_{s}\right)}\left(1-\frac{\sigma_{a}}{\sigma_{0}}\right)}{1+\frac{G_{\infty}}{G_{l}} \frac{\left(1-2 \nu_{l}\right) a^{2}+b^{2}}{a^{2}-b^{2}} \psi\left(t_{s}+t\right)} \sigma_{0} \\
& t=0 \text { のとき: } \\
& p_{a}=\frac{\sigma_{a}}{1+\frac{G_{\infty}}{G_{l} \cdot \phi\left(t_{c}\right)} \frac{\left(1-2 \nu_{l}\right) a^{2}+b^{2}}{a^{2}-b^{2}}} \\
& \text { ここに } \begin{array}{l}
\psi\left(t_{s}+t\right)=a^{\prime}-b^{\prime} \log \left(t_{s}+t\right), \\
\phi\left(t_{c}\right) \cdot \psi\left(t_{s}\right)=1
\end{array}
\end{aligned}
$$

上式によって覆工土圧 $p$ の諸条件に対する特性を知る ことができる。すなわち, $p$ は覆工設置後の経過時間 $t$ とともに増大するが，長時間後には一定值に漸近する。 $p$ は $\sigma_{0}$ すなわちトンネル土被の大きいほど大きくなり, また坑内に入れた圧気圧 $\sigma_{a}$ の高いほどそれを除圧した ときの $p$ は大きくなる。通常覆工の弾性係数 $G_{l}$ は地山 の弾性係数 $G_{\infty}$ より大きいが， $G_{l}$ が大きいほど，すな わち覆工の剛度が高いほどpは大きい。完全に剛な覆工 では $G_{l} \rightarrow \infty$ として 式 (40) 第 1 式の分母第 2 項は無 視できる。便宜上, 完全に剛な覆工に対する $p$ の特性を みると, $p$ は $\log \left(t_{s}+t\right)$ に比例して増加し, また覆工 施工前の素掘り期間 $t_{c}$ が長いほど, $\psi\left(t_{s}+t\right) / \psi\left(t_{s}\right)$ の 值が 1 に近づくから，地山の破壊が生じない限り，覆工 設置時期を遅らせれば，それだけ将来発生する覆工土圧
の大きさは小さくなる。

\section{4. 重カの場にある粘弾性地山中のトンネル土 圧}

\section{（1）はしがき}

重力の場にある粘弾性地山中に開削した円形トンネル の土圧の経時変化を解明するには前述 3. の場合と同様 に，重力の場にある等方均質な純弾性体中の円形トンネ ルの応力・ひずみの解に time factor を導入することに よって解明することができる。ゆえにまず半無限弾性体 地山に対する応力・ひずみの解を求める必要があるが， この解についてはすでにいくつかの成果が発表されてい るのでそれの援用をうけることができる。弾性解として は 2 次元問題として, 素掘りトンネルの周辺地山の応力 は, Hanns Schmid ${ }^{4}$, 山口年 ${ }^{5)}$, N. Muskhelishvili ${ }^{6}$ などによって研究され，また覆工のある円形トンネルの 地中応力や覆工土圧については, 前記 $\mathrm{Schmid}^{4)}$, 谷本 勉之助 ${ }^{7}$ ，小田英一 ${ }^{8)}$ などによって研究されている。

これらのうち Schmid の解は早期の研究として注目す べきものであるが，方程式の解に近似が用いられている 部分が多いことと，覆工をもつトンネルでは地山の変位 のうち剛体変位 (rigid body displacement) が分離さ れていないなどの欠点があって，ここに適用することは 適当でないようである。一方谷本は，この解析を Airy の応力関数とこの関数に J.H. Michell の提案した式を 用いて進めており，谷本の解俉工を覆工略する条件を入 れれば山口 ${ }^{5}$ の求めた素掘りトンネルの場合の解と一致 することが確かめられている7) など適用性が高い。しか し谷本の解では, 地山と地山にはめこまれた覆工が重力 をうけて変形したとき, 覆工と地山の接触面における境 界条件として，(1) 接触面の両側で半径方向の直応力と 接触面にそうせん断応力が連続であり，(2) 接触面にお いて覆工と地山の間に変形のずれがないことに仮定して いる。この境界条件を具体例によってたとえれば，薄い 四角な箱を水平に置いてその中に軟い弾性体を一杯みた し，それにあまり大きくない円孔を鉛直にあけ，この円 孔にちようど合致するやや硬い弾性リングを鉛直に挿入 したのち，箱にふたをしてそれを鉛直に立てて中味全体 が自重で変形したとき, 弾性リング外周に生ずる応力を 覆工土圧としたものである。

上述の境界条件のうち (2) の変形条件は, 地山を開削 した後に覆工を構築するといら実際の施工条件と一致し ないからここには適用できない。そこでここでは, 山口 の解と, 谷本の解のうち (2) の境界条件を導入する以前 の部分との援用をらけ，3.(1) にのべたようにトンネル 
開削に伴う弾性地山の応力増分のために生ずる開削面の 変形に注目し,さらにこれを粘弾性地山に拡張し, 式(38) と同じ主旨の変形条件を用いて解析することとする。

\section{（2）重力の場にある弾性地山中の円形トンネル}

ここでは表題に関する山口と谷本の解の概要を記す。

谷本 ${ }^{7)}$ は重力の場にある半無限弾性体中に弾性覆工を もつ円形トンネルがある場合, 地山あるいは覆工の応力 をこれらがトンネル軸に対して平面ひずみ状態にあると して次の上うに解いている。いま図一4 左半のように覆 工中心に原点をおく極座標をとり，地山あるいは覆工の

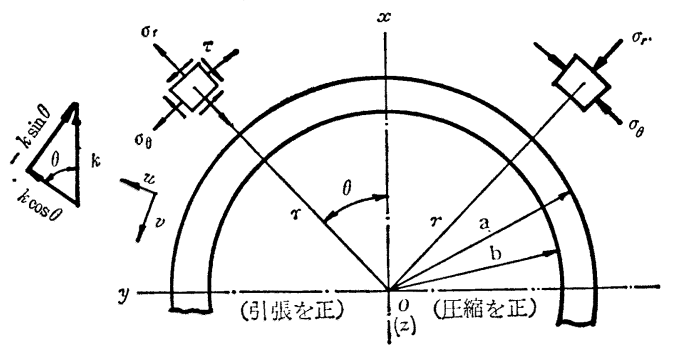

図一4 座標 (右半 : 圧縮が正の場合, 左半 : 引張が 正の場合）

応力 (ここでは谷本にならい直応力は引張を正とする) を応力関数 $\phi$ と地山または覆工の単位体積重量 $r_{s}$ (深さ により不変と仮定）を用いて示すと次のようになる。

$$
\left.\begin{array}{l}
\sigma_{r}=\frac{1}{r} \frac{\partial \phi}{\partial r}+\frac{1}{r^{2}} \frac{\partial^{2} \phi}{\partial \theta^{2}}+r_{s} \cdot r \cdot \cos \theta, \\
\sigma_{\theta}=\frac{\partial^{2} \phi}{\partial r^{2}}+r_{s} \cdot r \cdot \cos \theta, \tau=-\frac{\partial}{\partial r}\left(\frac{1}{r} \frac{\partial \phi}{\partial \theta}\right)
\end{array}\right\}
$$

上式の応力関数 $\phi$ は, 極座標表示の重調和関数 $\left(\nabla^{4} \phi=0\right)$ で, J.H. Michell により， $a_{0}, b_{0}$ などの未定係数を用 いて次式で与えられる。

$$
\begin{aligned}
\phi & =\left(a_{0} \log r+b_{0} r^{2}+c_{0} r^{2} \log r\right)+d_{0} r^{2} \theta+d_{0}{ }^{\prime} \theta \\
& +(1 / 2)\left(a_{1} r \theta \sin \theta+c_{1} r \theta \cos \theta\right) \\
& +\left(b_{1} r^{3}+a_{1}{ }^{\prime} r^{-1}+b_{1}{ }^{\prime} r \log r\right) \cos \theta \\
& +\left(d_{1} r^{3}+c_{1}{ }^{\prime} r^{-1}+d_{1}{ }^{\prime} r \log r\right) \sin \theta \\
& +\sum_{n=2}^{\infty}\left(A_{n} \cos n \theta+B_{n} \sin n \theta\right) \\
\text { こに, } & A_{n}=a_{n} r^{n}+b_{n} r^{n+2}+a_{n}{ }^{\prime} r^{-n}+b_{n}{ }^{\prime} r^{-n+2}, \\
& B_{n}=c_{n} r^{n}+d_{n} r^{n+2}+c_{n}{ }^{\prime} r^{-n}+d_{n}{ }^{\prime} r^{-n+2}
\end{aligned}
$$

なお $\Sigma$ の項中の $n \geqq 4$ の項は応力・ひずみに与える影 響が小さいから無視して， $n=2,3$ のみを採用すると $\phi$ は全部で 29 個の未定係数を持つこととなる。応力は座 標の鉛直軸に関して対称であるから，軸対称の条件から 次の係数は 0 となるが, なお 14 個の未定係数が残る。

$$
\begin{aligned}
& c_{0}=c_{1}=c_{1}{ }^{\prime}=c_{n}=c_{n}{ }^{\prime}=0 \\
& d_{0}=d_{0}{ }^{\prime}=d_{1}=d_{1}{ }^{\prime}=d_{n}=d_{n}{ }^{\prime}=0 \quad(n=2,3)
\end{aligned}
$$

したがって各応力は式 (41)，(42) より次のようになる。

$$
\begin{aligned}
\sigma_{r}= & a_{0} r^{-2}+2 b_{0} \\
& +\left(a_{1} / r+2 b_{1} r+\gamma_{s} r-2 a_{1}{ }^{\prime} / r^{3}+b_{1}{ }^{\prime} / r\right) \cos \theta \\
& +\left(-2 a_{2}-6 a_{2}{ }^{\prime} / r^{4}-4 b_{2}{ }^{\prime} / r^{2}\right) \cos 2 \theta \\
& +\left(-6 a_{3} r-4 b_{3} r^{3}-12 a_{3}{ }^{\prime} / r^{5}-10 b_{3}{ }^{\prime} / r^{3}\right) \cos 3 \theta \\
\sigma_{\theta}= & -a_{0} r^{-2}+2 b_{0} \\
& +\left(6 b_{1} r+r_{s} r+2 a_{1}{ }^{\prime} / r^{3}+b_{1}{ }^{\prime} / r\right) \cos \theta \\
& +\left(2 a_{2}+12 b_{2} r^{2}+6 a_{2}{ }^{\prime} / r^{4}\right) \cos 2 \theta \\
& +\left(6 a_{3} r+20 b_{3} r^{3}+12 a_{3}{ }^{\prime} / r^{5}+2 b_{3}{ }^{\prime} / r^{3}\right) \cos 3 \theta \\
\tau= & \left(2 b_{1} r-2 a_{1}{ }^{\prime} / r^{3}+b_{1}{ }^{\prime} / r\right) \sin \theta \\
& +\left(2 a_{2}+6 b_{2} r^{2}-6 a_{2}{ }^{\prime} / r^{4}-2 b_{2}{ }^{\prime} / r^{2}\right) \sin 2 \theta \\
& +\left(6 a_{3} r+12 b_{3} r^{3}-12 a_{3}{ }^{\prime} / r^{5}-6 b_{3}{ }^{\prime} / r^{3}\right) \sin 3 \theta
\end{aligned}
$$

一方, 山口 ${ }^{5)}$ は, 上述の場合と同一の条件のもとで半 無限弹性体に円孔のない場合と, 円形の素掘りトンネル のある場合の地山の応力を次のように求めた。

a） トンネル開削前の円孔のない自然堆積状態の場合

$$
\left.\begin{array}{rl}
\sigma_{r 0}= & -\left\{\frac{2-\beta}{2}-\frac{4-\beta}{4}\left(\frac{r}{H}\right) \cos \theta\right. \\
& \left.+\frac{\beta}{2} \cos 2 \theta-\frac{\beta}{4}\left(\frac{r}{H}\right) \cos 3 \theta\right\} \cdot \sigma_{0} \\
\sigma_{\theta 0}= & -\left\{\frac{2-\beta}{2}-\frac{4-3 \beta}{4}\left(\frac{r}{H}\right) \cos \theta\right. \\
& \left.-\frac{\beta}{2} \cos 2 \theta+\frac{\beta}{4}\left(\frac{r}{H}\right) \cos 3 \theta\right\} \cdot \sigma_{0} \\
\tau_{0}= & -\left\{\frac{\beta}{4}\left(\frac{r}{H}\right) \sin \theta-\frac{\beta}{2} \sin 2 \theta\right. \\
& \left.+\frac{\beta}{4}\left(\frac{r}{H}\right) \sin 3 \theta\right\} \cdot \sigma_{0}
\end{array}\right\}
$$

ここに, $\beta=1-\{\nu /(1-\nu)\}, \nu:$ ポアソン比,

$\sigma_{0}=\gamma_{s} \cdot H, H:$ トンネル中心以上の土かぶり高さ

b） 円形素掘りトンネルのある場合

自然堆積状態の弾性地山に半径 $a$ の素掘りの円孔を開 削することにより地山の応力が式 (44) の值以上に増加 する量を $\sigma_{r c}-\sigma_{r 0}, \sigma_{\theta c}-\sigma_{\theta 0}, \tau_{c}-\tau_{0}$ とすれば, (添字 : $c$ )

$$
\left.\begin{array}{rl}
\sigma_{r c}-\sigma_{r 0}= & {\left[\frac{2-\beta}{2}-\frac{4-\beta}{4}\left(\frac{r}{H}\right) \cos \theta+\frac{\beta}{2}\left\{4-3\left(\frac{a}{r}\right)^{2}\right\} \cos 2 \theta\right.} \\
\left.-\frac{\beta}{4}\left(\frac{r}{H}\right)\left\{5\left(\frac{a}{r}\right)^{2}-4\left(\frac{a}{r}\right)^{4}\right\} \cos 3 \theta\right] \cdot\left(\frac{a}{r}\right)^{2} \cdot \sigma_{0} \\
\sigma_{\theta c}-\sigma_{\theta 0}=-\left[\frac{2-\beta}{2}-\frac{\beta}{4}\left(\frac{r}{H}\right) \cos \theta-\frac{3 \beta}{2}\left(\frac{a}{r}\right)^{2} \cos 2 \theta-\frac{\beta}{4}\left(\frac{r}{H}\right)\left\{\left(\frac{a}{r}\right)^{2}-4\left(\frac{a}{r}\right)^{4}\right\} \cos 3 \theta\right] \cdot\left(\frac{a}{r}\right)^{2} \cdot \sigma_{0} \\
\tau_{c}-\tau_{0}=+\left[\frac{\beta}{4}\left(\frac{r}{H}\right) \sin \theta+\frac{\beta}{2}\left\{2-3\left(\frac{a}{r}\right)^{2}\right\} \sin 2 \theta-\frac{\beta}{4}\left(\frac{r}{H}\right)\left\{3\left(\frac{a}{r}\right)^{2}-4\left(\frac{a}{r}\right)^{4}\right\} \sin 3 \theta\right] \cdot\left(\frac{a}{r}\right)^{2} \cdot \sigma_{0}
\end{array}\right\}
$$


上式から明らかなように，半径 $a$ の円孔を開削したた め増加した応力は $(a / r)^{2}$ に比例して減少し, $r \rightarrow \infty て ゙$ は 0 となる。また式 (43) は地山にも覆工にも適用でき るが, 地山の場合は $r \rightarrow \infty$ において式 (43) の $\sigma_{r}$, $\sigma_{\theta}, \tau$ はそれぞれ式 (44) の $\sigma_{r 0}, \sigma_{\theta 0}, \tau_{0}$ に一致せねばな らない。この一致の条件から式 (43) のうち次の式(46) の 6 個の未定係数を決定することができるので，式(43) にはなお 8 個の末定係数が末知数として残る。

$$
\begin{aligned}
& a_{2}=\beta \cdot \sigma_{0} / 4, a_{3}=-\beta \cdot \sigma_{0} /(24 \cdot H), \\
& b_{0}=-(2-\beta) \cdot \sigma_{0} / 4, \quad b_{1}=-\beta \cdot \sigma_{0} /(8 \cdot H), \\
& b_{2}=b_{3}=0
\end{aligned}
$$

次に, 弾性体中の一点において $r, \theta$ それぞれの増す 方向にはかった変位 $u, v$ は弾性体中の応力 $\sigma_{r}, \sigma_{\theta}$ を積 分して次のよらに求められる7゙。

$$
\left.\begin{array}{rl}
u= & {\left[(\lambda+2 \mu) \int \sigma_{r} d r-\lambda \int \sigma_{\theta} d r+k \cdot \cos \theta\right] /\{4 \mu(\lambda+\mu)\}} \\
v= & {\left[-(\lambda+2 \mu)\left\{\int d \theta \int \sigma_{r} d r-r \int \sigma_{\theta} d \theta\right\}\right.} \\
& \left.+\lambda\left\{\int d \theta \int \sigma_{\theta} d r-r \int \sigma_{r} d \theta\right\}-k \cdot \sin \theta\right] /\{4 \mu(\lambda+\mu)\}
\end{array}\right\}
$$

ここに, $\lambda, \mu$ は Lamé の定数, $k$ は末定の積分定数で ある。 $k$ は， $k$ が正であれば，図一4 のように $u$ (また は $r$ ) 方向の $k \cos \theta$ と $v($ また $\theta$ ) と反対方向の $-k \sin \theta$ を合成したものであるから鉛直上向きの成分 である。また $u, v$ は前述のように覆工中心を原点にし て測っている。ゆえに $k$ が正であれば $k /\{4 \mu(\lambda+\mu)\}$ は地山全体が覆工中心を基準にして上昇する変位, すな わち覆工に対する地山の上向きの剛体変位を表わしてい る。なお $k$ は未定であるから, 地山に対しては未知の未 定係数 8 個とあわせると地山での未知数の数は 9 個とな る。

式 (47) のように弾性体中の一点 $(r, \theta)$ の変位 $u, v$ は $\sigma_{r}$ と $\sigma_{\theta}$ の一次の項の積分で示されるが, この積分 式は長いので式 (47) 第 1，2式の右辺をそれぞれ次式 のように関数 $F_{u}, F_{v}$ を用いて簡単に表現することとす る。

$$
\left.\begin{array}{l}
u(r, \theta)=F_{u}\left(\sigma_{r}, \sigma_{\theta}, \lambda, \mu, k\right) \\
v(r, \theta)=F_{v}\left(\sigma_{v}, \sigma_{\theta}, \lambda, \mu, k\right)
\end{array}\right\}
$$

なお Lamé の定数 $\lambda, \mu$ とせん断弹性係数 $G$, ポア ソン比ンとの間には次の関倸がある。

$$
\lambda=2 \nu G /(1-2 \nu), \mu=G \text {. }
$$

式 (47) に式 (43) の $\sigma_{r}, \sigma_{\theta}$ を代入して $u, v$ を求める と,

$$
\begin{aligned}
4 & \mu(\lambda+\mu) \cdot u=-2(\lambda+\mu) r^{-1} a_{0}+4 \mu r b_{0}+k \cos \theta \\
& +\left\{(\lambda+2 \mu) \log r \cdot a_{1}+2(-\lambda+\mu) r^{2} \cdot b_{1}\right. \\
& \left.+2(\lambda+\mu) r^{-2} \cdot a_{1}{ }^{\prime}+2 \mu \log r \cdot b_{1}{ }^{\prime}+\mu r_{s} r^{2}\right\} \cos \theta \\
& +\left\{-4(\lambda+\mu) r \cdot a_{2}+4(-\lambda) r^{3} \cdot b_{2}\right. \\
& \left.+4(\lambda+\mu) r^{-3} \cdot a_{2}{ }^{\prime}+4(\lambda+2 \mu) r^{-1} \cdot b_{2}{ }^{\prime}\right\} \cos 2 \theta
\end{aligned}
$$

$$
\begin{aligned}
& +\left\{-6(\lambda+\mu) r^{2} \cdot a_{3}-2(3 \lambda+\mu) r^{4} \cdot b_{3}\right. \\
& \left.+6(\lambda+\mu) r^{-4} \cdot a_{3}{ }^{\prime}+2(3 \lambda+5 \mu) r^{-2} \cdot b_{3}{ }^{\prime}\right\} \cos 3 \theta \\
4 \mu & (\lambda+\mu) \cdot v=0 \times a_{0}+0 \times b_{0}-k \cdot \sin \theta \\
& +\left[-\{\lambda+(\lambda+2 \mu) \log r\} a_{1}+2(3 \lambda+5 \mu) r^{2} \cdot b_{1}\right. \\
& \left.+2(\lambda+\mu) r^{-2} a_{1}{ }^{\prime}+2 \mu(1-\log r) b_{1}{ }^{\prime}+\mu r_{s} r^{2}\right] \sin \theta \\
& +\left\{4(\lambda+\mu) r \cdot a_{2}+4(2 \lambda+3 \mu) r^{3} \cdot b_{2}\right. \\
& \left.+4(\lambda+\mu) r^{-3} \cdot a_{2}{ }^{\prime}+4(-\mu) r^{-1} \cdot b_{2}{ }^{\prime}\right\} \sin 2 \theta \\
& +\left\{6(\lambda+\mu) r^{2} \cdot a_{3}+2(5 \lambda+7 \mu) r^{4} b_{3}\right. \\
& \left.+6(\lambda+\mu) r^{-4} \cdot a_{3}{ }^{\prime}+2(\lambda-\mu) r^{-2} \cdot b_{3}{ }^{\prime}\right\} \sin 3 \theta
\end{aligned}
$$

一方 $\tau$ と $u, v$ の関倸は

$$
\tau=\mu\left[\frac{1}{r} \cdot \frac{\partial u}{\partial \theta}+\left(\frac{\partial}{\partial r}-\frac{1}{r}\right) v\right]
$$

そこで上式に式 (50) の $u, v$ を代入したものと式 (43) の $\tau$ を比べると, 係数 $b_{1}{ }^{\prime}$ と $a_{1}$ の関係が次のように えられる。

$$
b_{1}{ }^{\prime}=-\mu \cdot a_{1} /(2 \lambda+4 \mu)
$$

そのため地山では未知数の数が 1 個減り 8 個が残る。

一方覆工の応力・変位についても, 式 (43), (49), (50)，(52) は重力の場にある軸対称の弹性体として地山 の場合と同様に成立する。ただし覆工の変位に対しては 覆工の中心を座標の原点にとっているから, 覆工の剛体 変位は 0 となるので, 式 (50) 中の $k$ は $k=0$ である。 未知の未定保数の数は式 (43) に 14 個あるが, 式 (52) の係数間の関倸式のため 1 個減り結局 13 個が残る。上 記の覆工の応力や変位の式を地山のそれらの式と区別す るため, 覆工関係の式中, 応力, 変位, 未定係数, 覆工 単位体積重量, Lamé の定数にはすべて添字 $l$ をつけて 示すこととする。

覆工と地山の応力・変位を解くためには, 地山につい て 8 個, 覆工で 13 個, 合計 21 個の未知数を求める必要 がある。谷本は 4. (1) にのべたように半径 $a$ の覆工外周 面に打ける応力の連続条件 $\left(r=a\right.$ にて, $\left.\sigma_{r}=\sigma_{r l}, \tau=\tau_{l}\right)$ と変位の連続条件 $\left(r=a\right.$ にて, $\left.u=u_{l}, v=v_{l}\right)$ および半 径 $b$ の覆工内面が無支持の条件 $\left(r=b\right.$ にて, $\sigma_{r l}=0$, $\left.\tau_{l}=0\right)$ の 3 境界条件を用いて上記 21 個の未知数の值を 求め, 弾性地山や覆工の応力・変位を解析した。

\section{（3）粘弾性地山における覆工土圧とその計算例}

粘弹性地山では 3. (5) にのべたように素掘り期間中は クリープが生じ, 覆工構築後は応力緩和がおこる。

自重によって初期ひずみを受けている自然堆積地山に 円形トンネルを開削したとき, 覆工構築をでの $t_{c}$ 時間 の素掘り期間中に生じた開削面のクリープ変位の radial の成分を $u_{c}$, tangential の成分を $v_{c}$ とする。 $u_{c}, v_{c}$ を測った基準面は開削前の開削面位置である。覆工構築 後 $t$ 時間後の地山の開削面の変位もこの基準から測って $u_{s}, v_{s}$ とする。覆工は地山の開削後 $t_{c}$ 時間後に無応力 
の状態で地山に密接して構築するとし, 構築時点以後 $t$ 時間の間に覆工外周面の変位する量を $u_{l}, v_{l}$ とすれば, 式(38)の場合と同一の主旨から次の変位条件が求まる。

$$
u_{l}=u_{s}-u_{c}, \quad v_{l}=v_{s}-v_{c}
$$

$u_{l}, v_{l}$ は覆工構築時点の覆工中心を座標原点としたと き, この原点に関する覆工の変位であり, $u_{c}, v_{c}$ および $u_{s}, v_{s}$ はそれぞれ地山開削面の開削前の中心を座標原点 として, この原点に関する地山開削面の変位である。地 山開削面が覆工構筑時点以後に変位する量は $u_{s}-u_{c}$, $v_{s}-v_{c}$ であるから, $u_{s}-u_{c}, v_{s}-v_{c}$ の座標原点は覆工 構築時点の地山開削面の中心に該当する。覆工構築時 $(t=0)$ には覆工中心 $\left(u_{l}, v_{l}\right.$ の原点) と地山開削面中 心 $\left(u_{s}-u_{c}, v_{s}-v_{c}\right.$ の原点) は当然一致しているが, 時 間が経過し $(t=t)$ では覆工に土圧が加わると変位の計 算上覆工中心と地山開削面中心は一致しなくなり, 両中 心すなわち両座標原点は離隔していわゆる剛体变位が発 生する。そこでここでは便宜上, 覆工構築時 $(t=0)$ に おける両中心の一致した点を剛体変位を測る基準点とす ることとした。

次に式 (53) 中の各項を式で示していくこととする。 まず覆工外周面の $t=t$ の時点における变位 $u_{l}, v_{l}$ は式 (50) 中の未定係数, Lamé の定数に覆工を示すための添 字 $l$ をつけ, 剛体変位を $k_{l}$, 単位体積重量を $r l$ と記し たのち, $r=a$ とおいた式で示される。この式は添字 $l$ と, $r$ をaにかえたほかは式 (50) と全く同一であるか ら式全体を記すことは省略してそのかわり以下の式(54) のよう略記する。式 (50) 亿含まれる未知数は未定係数 14 個と $k_{l} 1$ 個があるが，式 (52) の関係があるから $b_{l_{1}}{ }^{\prime}$ を除けば末知数は 14 個となり，それらはすべて一 次結合で示されている。いま $f_{l}, \varphi_{l}$ をこれら未知数の 一次式を示す関数（関数の内容は式 (50) と対照すれば 自明) として $u_{l}, v_{l}$ を示すと，

$$
\begin{aligned}
& u_{l}=f_{l 0}\left(a_{l 0}, b_{l_{0}}\right)+f_{l_{1}}\left(a_{l_{1}}, b_{l_{1}}, a_{l_{1}}{ }^{\prime}, k_{l}\right) \cos \theta \\
& +f_{l_{2}}\left(a_{l 2}, b_{l 2}, a_{l_{2}}{ }^{\prime}, b_{l_{2}}{ }^{\prime}\right) \cos 2 \theta \\
& +f_{l 3}\left(a_{l 3}, b_{l 3}, a_{l 3}{ }^{\prime}, b_{l^{\prime}}{ }^{\prime}\right) \cos 3 \theta \\
& v_{l}=\varphi_{l_{1}}\left(a_{l_{1}}, b_{l_{1}}, a_{l_{1}}{ }^{\prime}, k_{l}\right) \sin \theta \\
& +\varphi_{l_{2}}\left(a_{l_{2}}, b_{l_{2}}, a_{l_{2}}{ }^{\prime}, b_{l_{2}}{ }^{\prime}\right) \sin 2 \theta \\
& +\varphi_{l 3}\left(a_{l 3}, b_{l 3}, a_{l 3}{ }^{\prime}, b_{l 3}{ }^{\prime}\right) \sin 3 \theta
\end{aligned}
$$

なお覆工は弾性体であるから， Lamé の定数 $\lambda_{l}, \mu_{l}$ は 時間に無関係に一定な定数である。

次汇応力緩和時の地山開削面の変位 $u_{s}, v_{s}$ は, 覆工構 築後 $t=t$ において地山の Lamé の定数が応力緩和の結
果 $\lambda_{s}, \mu_{s}$ （せん断弹性係数： $G_{s}$ ）になったとき,トンネ ル開削の結果生じた地山の応力増分 $\sigma_{r s}-\sigma_{r 0}, \sigma_{\theta s}-\sigma_{\theta 0}$ によって生じた開削面の変位である。ここに $\sigma_{r s}, \sigma_{\theta s}$ は, 無応力状態の地山に円孔をあけ, ある接触圧にて弾性覆 工をはめこんだのち地山を重力の場に移したときの地山 中の一点 $(r, \theta)$ に打汀応力に相当し, その応力の值 は覆工と地山の最初の接触圧によるのでここでは未知数 である。一方 $\sigma_{r 0}, \sigma_{\theta 0}$ は, この点 $(r, \theta)$ が重力の場に ある開削前の無孔の自然地山に打いて示方初期応力であ って式 (44)によって与えられる。Lamé の定数と $G_{s}$ の関係には式 (49) があるが, ここでは地山のポアソン 比义はつねに一定と仮定する。 $u_{s}, v_{s}$ を応力增分を用い 式 (48) にならって示すと,

$$
\left.\begin{array}{l}
u_{s}=F_{u}\left[\left(\sigma_{r s}-\sigma_{r 0}\right),\left(\sigma_{\theta s}-\sigma_{\theta 0}\right), \lambda_{s}, \mu_{s}, k_{s}\right]_{r=a} \\
v_{s}=F_{v}\left[\left(\sigma_{r s}-\sigma_{r 0}\right),\left(\sigma_{\theta s}-\sigma_{\theta 0}\right), \lambda_{s}, \mu_{s}, k_{s}\right]_{r=a}
\end{array}\right\}
$$

$u_{s}, v_{s}$ はともに地山応力の一次式であり, また, $u_{s}, v_{s}$ に対する剛体変位は $k_{s} 1$ 個で十分であるから, 上式を 次の式 (56) の上うに書きかえる場合 $u_{s 0}, v_{s 0}$ を示す式 にのみ $k_{s}$ をつけ, $u_{0}, v_{0}$ の式には剛体変位はつける必 要はない。

$$
\begin{aligned}
& u_{s}=u_{s 0}-u_{0}, v_{s}=v_{s 0}-v_{0} \\
& u_{s 0}=F_{u}\left(\sigma_{r s}, \sigma_{\theta s}, \lambda_{s}, \mu_{s}, k_{s}\right)_{r=a} \\
& u_{0}=F_{u}\left(\sigma_{r 0}, \sigma_{\theta 0}, \lambda_{s}, \mu_{s}\right)_{r=a} \\
& v_{s 0}=F_{v}\left(\sigma_{r s}, \sigma_{\theta s}, \lambda_{s}, \mu_{s}, k_{s}\right)_{r=a} \\
& v_{0}=F_{v}\left(\sigma_{r 0}, \sigma_{\theta 0}, \lambda_{s}, \mu_{s}\right)_{r=a}
\end{aligned}
$$

すなわち $u_{s}$ または $v_{s}$ は, 円形覆工を装備した Lamé の定数 $\lambda_{s}, \mu_{s}$ の弾性体の $\sigma_{r s}, \sigma_{\theta s}$ による開削面の変位 量 $u_{s 0}$ または $v_{s 0}$ と, 同一の Lamé の定数 $\lambda_{s}, \mu_{s}$ の 開削前の無孔の弾性体の $\sigma_{r 0}, \sigma_{\theta 0}$ による開削面に相等す る開削前の位置の初期変位量 $u_{0}$ または $v_{0}$ との差とし て与えられる。なお， $\lambda_{s}, \mu_{s}$ は式 (20) を式 (49) に代 入して求められるもので, 素掘り期間 $t_{c}$ と覆工構築後 の経過時間 $t$ の 2 つ時間要素が含まれるから時間依存 性の係数である。

式 (56) 中の $u_{s 0}, v_{s 0}$ は, 式 (50) 中の Lamé の定 数に添字 $s$ をつけ $k$ を $k_{s}$ にかえたのち $r=a$ とおいた 以外は式 (50) と全く同一であるからここに再記を省略 する。

また式 (56) 中の $u_{0}, v_{0}$ は式 (47) の $\sigma_{r}, \sigma_{\theta}$ に式(44) の $\sigma_{r 0}, \sigma_{\theta 0}$ を代入した式において Lamé の定数に添字 $s$ をつけたのち $r=a$ とおいた次式で示される。なお上記 のように剛体変位はつける必要がないから $k=0$ とした。

$$
\left.\begin{array}{l}
-4 \mu_{s}\left(\lambda_{s}+\mu_{s}\right) u_{0}=\left[\mu_{s}(2-\beta) a-\left(\lambda_{s}-\mu_{s}+4 \mu_{s} / \beta\right) \beta\left(a^{2} / 4 H\right) \cos \theta\right. \\
\left.\quad+\left(\lambda_{s}+\mu_{s}\right) \beta \cdot a \cdot \cos 2 \theta-\left(\lambda_{s}+\mu_{s}\right) \beta\left(a^{2} / 4 H\right) \cos 3 \theta\right] \cdot \sigma_{0} \\
-4 \mu_{s}\left(\lambda_{s}+\mu_{s}\right) v_{0}=\left[\left(3 \lambda_{s}+5 \mu_{s}-4 \mu_{s} / \beta\right) \beta\left(a^{2} / 4 H\right) \sin \theta-\left(\lambda_{s}+\mu_{s}\right) \beta \cdot a \cdot \sin 2 \theta\right. \\
\left.\quad+\left(\lambda_{s}+\mu_{s}\right) \beta\left(a^{2} / 4 H\right) \sin 3 \theta\right] \cdot \sigma_{0}
\end{array}\right\}
$$


地山に関する未定係数には式 (46)，(52）の関係があ るので, 式 (50) に含まれる末知数の数は未定係数 7 個 と $k_{s} 1$ 個で合計 8 個がある。式 (57) の各項は既知数 であるから $u_{s}\left(=u_{s 0}-u_{0}\right), v_{s}\left(=v_{s 0}-v_{0}\right)$ の式中にはこ れら 8 個の未知数が含まれ，それらは式 (50) にみられ るように一次結合をしている。いまこの未知数の一次式 を $f_{s}, \varphi_{s}$ の関数で示して $u_{s}, v_{s}$ を表わすと

$$
\left.\begin{array}{rl}
u_{s}=f_{0 s}\left(a_{0}\right) & +f_{1 s}\left(a_{1}, a_{1}{ }^{\prime}, k_{s}\right) \cos \theta \\
& +f_{2 s}\left(a_{2}{ }^{\prime}, b_{2}{ }^{\prime}\right) \cos 2 \theta \\
& +f_{3 s}\left(a_{3}{ }^{\prime}, b_{3}{ }^{\prime}\right) \cos 3 \theta \\
v_{s}=\varphi_{1 s}\left(a_{1},\right. & \left.a_{1}{ }^{\prime}, k_{s}\right) \sin \theta \\
& +\varphi_{2 s}\left(a_{2}{ }^{\prime}, b_{2}{ }^{\prime}\right) \sin 2 \theta \\
& +\varphi_{3 s}\left(a_{3}{ }^{\prime}, b_{3}{ }^{\prime}\right) \sin 3 \theta
\end{array}\right\}
$$

次に式(53) で示す素掘り終期の地山開削面の変位 $u_{c}$, $v_{c}$ は前述の説明からも分かるように次式で示される。

$$
\left.u_{c}=F_{u}\left[\left(\sigma_{r c}-\sigma_{r 0}\right),\left(\sigma_{\theta c}-\sigma_{r 0}\right), \lambda_{c}, \mu_{c}\right]_{r=a}\right)
$$

上式の $u_{c}, v_{c}$ は式 (47) に式 (45) を代入し, Lamé の 定数に添字 $c$ をつけたのち $r=a$ とおいたもので, 代入 した結果は次の式 (60) となる。トンネル開削後 $t_{c}$ 時 間経過した素掘り終期の Lamé の定数 $\lambda_{c}, \mu_{c}$ は式(49) の $G$ に式 (9) の $G_{c}$ を代入して求められる。ここでは 地山のポアソン比 $\nu$ は不変と仮定した。また $u_{c}, v_{c}$ に 対する剛体変位は, $u_{c}, v_{c}$ の時点を剛体変位の基準とし たから 0 である。素掘り期間 $t_{c}$ が既知であれば, 式(60) には末知数は含まれない。

$$
\left.\begin{array}{c}
-4 \mu_{c}\left(\lambda_{c}+\mu_{c}\right) u_{c}=\left[\left(\lambda_{c}+\mu_{c}\right)(2-\beta) a+2\left(2 \lambda_{c}+4 \mu_{c}\right.\right. \\
\left.-\mu_{c} \beta\right) \log a\left(a^{2} / 4 H\right) \cos \theta+\left(\lambda_{c}+3 \mu_{c}\right) \beta a \cdot \cos 2 \theta \\
\left.-\left(\lambda_{c}+3 \mu_{c}\right) \beta\left(a^{2} / 4 H\right) \cos 3 \theta\right] \cdot \sigma_{0} \\
-4 \mu_{c}\left(\lambda_{c}+\mu_{c}\right) v_{c}=\left[-2\left\{\left(2 \lambda_{c}+4 \mu_{c}-\mu_{c} \beta\right) \log a+\left(2 \lambda_{c}\right.\right.\right. \\
\left.\left.+\mu_{c} \beta\right)\right\}\left(a^{2} / 4 H\right) \sin \theta-\left(\lambda_{c}+3 \mu_{c}\right) \beta a \cdot \sin 2 \theta \\
\left.+\left(\lambda_{c}+3 \mu_{c}\right) \beta\left(a^{2} / 4 H\right) \sin 3 \theta\right] \cdot \sigma_{0}
\end{array}\right\}
$$

以上で開削面の変位条件式 (53) 中のすべての項は式 (54)〜 (60)によって未知の未定係数と剛体変位の一次式 で示すことができた。それら各項を式 (53) の第 1 式と 第 2 式に代入すると 2 つ連立一次方程式となる。この 両式中の剛体変位の項をとりだすと, 式 (47) の式の形 からも分かるように, 次式左辺で示す項が得られる。

$$
\frac{k_{s}}{4 \mu_{s}\left(\lambda_{s}+\mu_{s}\right)}-\frac{k_{l}}{4 \mu_{l}\left(\lambda_{l}+\mu_{l}\right)}\left(\equiv w_{1}\right)
$$

上式を $w_{1}$ と記すが， $w_{1}$ は $t=0$ における覆工中心を 基準として測った $t$ 時間経過後の地山開削面中心の変位 (地山の剛体変位) と覆工中心の変位(覆工の剛体変位) との差である。したがって $w_{1}$ は $t=t$ の時点における 覆工中心位置を基準として測った地山の相対的な剛体変 位に相当し，式 (53) の説明で明らかなように， $w_{1}$ は $t=0$ では 0 である。また連立方程式中の未知数の数は地 山では 8 個 (らち 1 個は剛体変位 $k_{s}$ ), 覆工では 14 個 (うち 1 個は剛体変位 $k_{l}$ ) で合計 22 個となる。しかし 式 (61) を用いて $k_{s}$ と $k_{l}$ の代わりに $k_{s}, k_{l}$ を 1 個の 末知数 $w_{1}$ で代表させれば,末知数の数は 21 個となる。 これらの未知数の決定には式 (53) のほかさらに次の 2 境界条件を用いる。

(a) 覆工外周面と地山開削面との接触面 $(r=a)$ に おける直応力とせん断応力の応力連続条件式 :

$$
\left(\sigma_{r s}\right)_{r=a}=\left(\sigma_{r l}\right)_{r=a},\left(\tau_{s}\right)_{r=a}=\left(\tau_{l}\right)_{r=a}
$$

(b) 覆工内面 $(r=b)$ の無支持に対する応力条件式：

$$
\left(\sigma_{r l}\right)_{r=b}=0,\left(\tau_{l}\right)_{r=b}=0
$$

式 (46)，(52）を考慮して式（43）を地山の応力式や添 字 $l$ をつけ覆工の応力式として式 (62) 第 1 , 第 2 式に 代入し, 得られた未知数の一次式を式 (54) と同様にそ れぞれ $f, \varphi$ の関数で表わすと

$$
\left.\begin{array}{l}
f_{0}\left(a_{0}, a_{l 0}, b_{l 0}\right)+f_{1}\left(a_{1}, a_{1}{ }^{\prime}, a_{l 1}, b_{l_{1}}, a_{l_{1}}{ }^{\prime}\right) \cos \theta \\
\quad+f_{2}\left(a_{2}{ }^{\prime}, b_{2}{ }^{\prime}, a_{l 2}, b_{l 2}, a_{l 2}{ }^{\prime}, b_{l_{2}}{ }^{\prime}\right) \cos 2 \theta \\
\quad+f_{3}\left(a_{3}{ }^{\prime}, b_{3}{ }^{\prime}, a_{l 3}, b_{l 3}, a_{l 3}{ }^{\prime}, b_{l 3}{ }^{\prime}\right) \cos 3 \theta=0 \\
\varphi_{1}\left(a_{1}, a_{1}{ }^{\prime}, a_{l_{1}}, b_{l_{1}}, a_{l_{1}}{ }^{\prime}\right) \sin \theta \\
\quad+\varphi_{2}\left(a_{2}{ }^{\prime}, b_{2}{ }^{\prime}, a_{l 2}, b_{l 2}, a_{l 2}{ }^{\prime}, b_{l 2}{ }^{\prime}\right) \sin 2 \theta \\
\quad+\varphi_{3}\left(a_{3}{ }^{\prime}, b_{3}{ }^{\prime}, a_{l 3}, b_{l 3}, a_{l 3}{ }^{\prime}, b_{l 3}{ }^{\prime}\right) \sin 3 \theta=0
\end{array}\right\}
$$

式 (63) に同様に $\sigma_{r l}, \tau_{l}$ を代大すると上式中の添字 $l$ をもつ項のみからなる未定係数の一次式 (記載省略) と なる。

式(53)，(62)，(63)の 3 式はいずれも $u$ または $\sigma_{r} に$ 関する第 1 式と $v$ または $\tau$ に関する第 2 式からなるか ら, 各式を末知数を含む式にかきなおすと末知数（末定 係数 20 個と $\left.w_{1}\right)$ の一次式からなる合計 6 個の連立方 程式となる。なおこれらの方程式のらち， $\sigma_{r}$ および $u$ に関する 3 式は数個の未知数の一次結合と $\cos n \theta$ (ただ し $n=0,1,2$ または 3 ) との積からなり, 一方 $\tau$ およ び $v$ に関する 3 式は未知数の一次結合と $\sin n \theta$ (ただ し $n=1,2$ または 3 ) との積からできている（たとえば 式 (64) 参照)。これら 6 個の連立方程式は $\theta$ のいかん にかかわらず成立せねばならないから $\cos n \theta, \sin n \theta$ のそれぞれの $n$ ごとにその乗数である一次結合の和は 0 となることが必要である。上記のように, $\cos n \theta$ の積 和を含む連立方程式の数は 3 個, 各連立方程式中の $n$ の 数は $n=0,1,2,3$ と計 4 個であるから，これら 3 連立 方程式から 12 個 $(3 \times 4=12)$ の方程式が得られる。ま た同様に $\sin n \theta$ をもつ 3 式では $n$ の数は, $n=1,2,3$ とそれぞれ 3 個であるから 9 個の方程式が得られる。こ のように 3 境界条件式より合計 21 個の一次式からなる 連立方程式が得られるので, それらの根として 21 個の 未知数の值を決定することができる。これら 21 個の方 
程式は $n=0,1,2,3$ に対して次の matrix 表示の式 (65)〜 (68) のように 4 群にわかれ， $n=0$ に属する 3 個 の連立方程式からは添字 0 をもつ 3 個の未定係数 $\left(a_{0}\right.$, $\left.u_{l 0}, b_{l 0}\right)$ が，また $n=1,2$ および 3 に属するそれぞれ 6 式からなる matrix で示した連立方程式からはそれぞれ 添字 1,2 および 3 をもつ各 6 個の未定係数または剛体

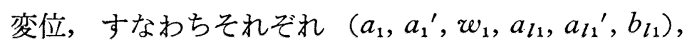

$\left(a_{2}{ }^{\prime}, b_{2}{ }^{\prime} a_{l 2}, a_{l 2}{ }^{\prime}, b_{l 2}, b_{l 2}{ }^{\prime}\right)$ および $\left(a_{3}{ }^{\prime}, b_{3}{ }^{\prime} a_{l 3}, a_{l 3}{ }^{\prime}\right.$, $\left.a b_{l}, b_{l 3^{\prime}}{ }^{\prime}\right)$ の 21 の值が求められる。前述のように Lamé の定数は素掘り期間 $t_{c}$, 覆工構筑後の経過時間 $t$ によっ て変化するから, それらの時間要素に応じて各時点の未 定係数と剛体变位が算定できる。ゆえにそれらを応力・ 変形の式に入れることによって地山や覆工の応力, 変 形, 覆工土圧などの経時変化を求めることができる。

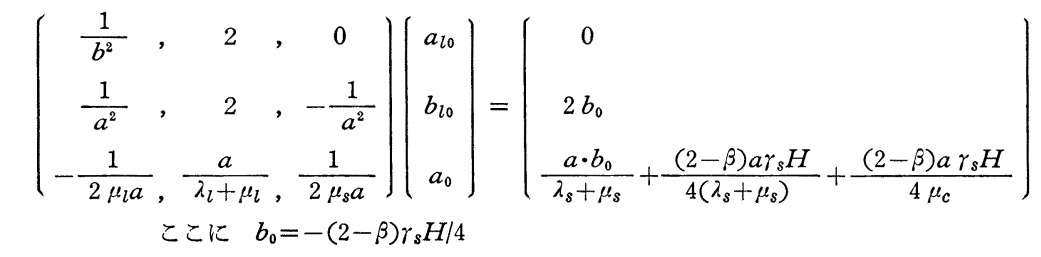

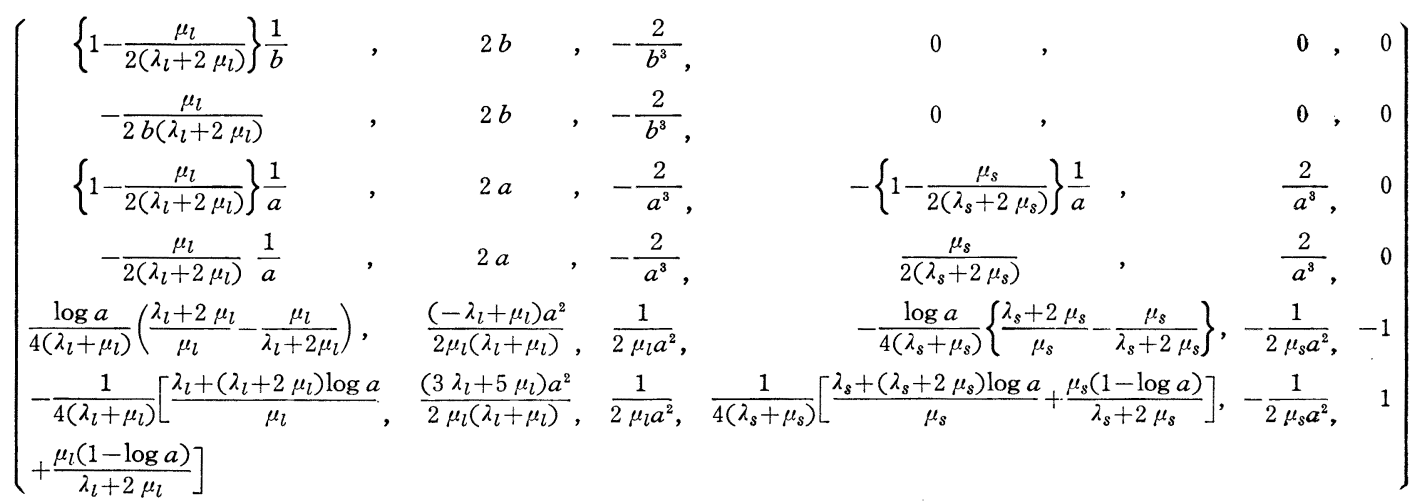

$$
\begin{aligned}
& \left(\begin{array}{l}
a_{l 1} \\
b_{l 1} \\
a_{l_{1}}{ }^{\prime} \\
a_{1} \\
a^{\prime} \\
w_{1} \\
\begin{array}{l}
2 a b_{1}+r_{s} a-r_{l} a \\
2 a b_{1} \\
\frac{-\left(\lambda_{s}-\mu_{s}\right)}{2 \mu_{s}\left(\lambda_{s}+\mu_{s}\right)} b_{1} a^{2}+\left[\frac{\gamma_{s}}{4\left(\lambda_{s}+\mu_{s}\right)}-\frac{\gamma_{l}{ }^{2}}{4\left(\lambda_{l}+\mu_{l}\right)}\right] a^{2}-\frac{\left(-\mu_{s}+\lambda_{s}+4 \mu_{s} / \beta\right)}{16 \mu_{s}\left(\lambda_{s}+\mu_{s}\right)} a^{2} \beta \gamma_{s}-\frac{\left(\mu_{c} \beta-2 \lambda_{c}-4 \mu_{c}\right)}{8 \mu_{c}\left(\lambda_{c}+\mu_{c}\right)} a^{2} \gamma_{s} \log a \\
\frac{3 \lambda_{s}+5 \mu_{s}}{2 \mu_{s}\left(\lambda_{s}+\mu_{s}\right)} a^{2} b_{1}+\left[\frac{\gamma_{s}}{4\left(\lambda_{s}+\mu_{s}\right)}-\frac{\gamma_{l}}{4\left(\lambda_{l}+\mu_{l}\right)}\right] a^{2}-\frac{\left(4 \mu_{s} / \beta-3 \lambda_{s}-5 \mu_{s}\right)}{16 \mu_{s}\left(\lambda_{s}+\mu_{s}\right)} a^{2} \beta \gamma_{s}-\left\{\frac{\left(2 \lambda_{c}+4 \mu_{c}-\mu_{c} \beta\right)}{8 \mu_{c}\left(\lambda_{c}+\mu_{c}\right)} a^{2} \gamma_{s} \log a\right. \\
\left.+\frac{a^{2} \gamma_{s}\left(2 \lambda_{c}+\mu_{c} \beta\right)}{8 \mu_{c}\left(\lambda_{c}+\mu_{c}\right)}\right\}
\end{array}
\end{array}\right) \\
& \text { ここに } b_{1}=-\frac{\beta \gamma_{s}}{8} \\
& \left(\begin{array}{ccccccc}
-2, & 0 & , & -\frac{6}{b^{4}}, & -\frac{4}{b^{2}}, & 0, & 0 \\
2, & 6 b^{2}, & -\frac{6}{b^{4}}, & -\frac{2}{b^{2}}, & 0, & 0 \\
-2, & 0, & -\frac{6}{a^{4}}, & -\frac{4}{a^{2}}, & \frac{6}{a^{4}}, & \frac{4}{a^{2}} \\
2, & \frac{6}{a^{2}}, & -\frac{6}{a^{4}}, & -\frac{2}{a^{2}}, & \frac{6}{a^{4}}, & \frac{2}{a^{2}} \\
-\frac{a}{\mu_{l}}, & \frac{-\lambda_{l} a^{3}}{\mu_{l}\left(\lambda_{l}+\mu_{l}\right)}, & \frac{1}{\mu_{l} a^{3}}, & \frac{\lambda_{l}+2 \mu_{l}}{\mu_{l}\left(\lambda_{l}+\mu_{l}\right) a}, & -\frac{1}{\mu_{s} a^{3}}, & -\frac{\lambda_{s}+2 \mu_{s}}{\mu_{s}\left(\lambda_{s}+\mu_{s}\right) a} \\
\frac{a}{\mu_{l}}, & \frac{\left(2 \lambda_{l}+3 \mu_{l}\right) a^{3}}{\mu_{l}\left(\lambda_{l}+\mu_{l}\right)}, & \frac{1}{\mu_{l} a^{8}}, & -\frac{1}{a\left(\lambda_{l}+\mu_{l}\right)}, & -\frac{1}{\mu_{s} a^{3}}, & \frac{1}{a\left(\lambda_{s}+\mu_{s}\right)}
\end{array}\right)\left(\begin{array}{c}
a_{l 2} \\
b_{l 2} \\
a_{l 2}{ }^{\prime} \\
b_{l 2}{ }^{\prime}
\end{array}\right)=\left(\begin{array}{c}
0 \\
0 \\
-\beta \frac{\gamma_{s} H}{2} \\
\beta \frac{\gamma_{s} H}{2} \\
a_{2}^{\prime} \\
\frac{H a \gamma_{s} \beta\left(\lambda_{c}+3 \mu_{c}\right)}{4 \mu_{c}\left(\lambda_{c}+\mu_{c}\right)} \\
-\frac{H a \gamma_{s} \beta\left(\lambda_{c}+3 \mu_{c}\right)}{4 \mu_{c}\left(\lambda_{c}+\mu_{c}\right)}
\end{array}\right)
\end{aligned}
$$




$$
\left(\begin{array}{cccccc}
-6 b & -4 b^{3}, & -\frac{12}{b^{5}}, & -\frac{10}{b^{3}}, & 0, & 0 \\
6 b & 12 b^{3}, & -\frac{12}{b^{5}}, & -\frac{6}{b^{3}}, & 0 & 0 \\
-6 a & -4 a^{3}, & -\frac{12}{a^{5}}, & -\frac{10}{a^{3}}, & \frac{12}{a^{5}}, & \frac{10}{a^{3}} \\
6 a & 12 a^{3}, & -\frac{12}{a^{5}}, & -\frac{6}{a^{3}}, & \frac{12}{a^{5}}, & \frac{6}{a^{3}} \\
-\frac{3 a^{2}}{2 \mu_{l}}, & \frac{\left(-3 \lambda_{l}-\mu_{l}\right)}{2 \mu_{l}\left(\lambda_{l}+\mu_{l}\right)} a^{4}, & \frac{3}{2 \mu_{l} a^{4}}, & \frac{3 \lambda_{l}+5 \mu_{l}}{2 \mu_{l}\left(\lambda_{l}+\mu_{l}\right) a^{2}}, & -\frac{3}{2 a^{4} \mu_{s}}, & -\frac{3 \lambda_{s}+5 \mu_{s}}{2 \mu_{s}\left(\lambda_{s}+\mu_{s}\right) a^{2}} \\
\frac{3 a^{2}}{2 \mu_{1}}, & \frac{5 \lambda_{l}+7 \mu_{l}}{2 \mu_{l}\left(\lambda_{l}+\mu_{l}\right)} a^{4}, & \frac{3}{2 \mu_{l} a^{4}}, & \frac{\lambda_{l}-\mu_{l}}{2 \mu_{l}\left(\lambda_{l}+\mu_{l}\right) a^{2}}, & -\frac{3}{2 a^{4} \mu_{s}}, & -\frac{\lambda_{s}-\mu_{s}}{2 \mu_{s}\left(\lambda_{s}+\mu_{s}\right) a^{2}}
\end{array}\right)\left(\begin{array}{c}
a_{l 3} \\
b_{l 3} \\
a_{l 3}{ }^{\prime} \\
b_{l s^{\prime}} \\
a_{3}{ }^{\prime} \\
b_{3}{ }^{\prime}
\end{array}\right)=\left(\begin{array}{c}
0 \\
\frac{a \beta \gamma_{s}}{4} \\
-\frac{a \beta \gamma_{s}}{4} \\
-\frac{\left(\lambda_{c}+3 \mu_{c}\right) a^{2} \gamma_{s} \beta}{16 \mu_{c}\left(\lambda_{c}+\mu_{c}\right)} \\
\frac{\left(\lambda_{c}+3 \mu_{c}\right) a^{2} \gamma_{s} \beta}{16 \mu_{c}\left(\lambda_{c}+\mu_{c}\right)}
\end{array}\right)
$$

本節 4. (3) でのべた重力の場を対象とした解は，3. にのべた等方圧の場合と次の点で内容が多少相違する。 すなわち自然地山を一次元的に自重で圧縮されたものと 考えると水平方向の初期ひずみはないから, 式 (21) 中 の $\varepsilon_{z 0}$ は本節の場合 $\varepsilon_{z 0}=0$ である。また 3. の等方圧 の場合は式 (33) のように $\sigma_{m}=0$ であるから開削面の 変位は地山のせん断ひずみにのみ基因しているが，4.の 場合は式 (43) の応力式からみられるよらに必ずしも $\sigma_{m}=0$ でない。ゆえに 4. の場合の開削面の変位は地山 のせん断ひずみのほかに若干の体積ひずみすなわち吸水 膨張や脱水圧密の過程も関係することとなる。ここでは 体積変化と $\sigma_{m}$ の関係は Lamé の定数を通じて表わして せん断変形の場合と同様に線形関係として扱ったことに なるが，体積変化に対する間げき水の加圧や移動につい ての時間過程については考えないこととした。

\section{【数値計算例】}

以上の解に数值を入れて覆工土圧 $\left(\sigma_{r}\right)_{r=a}$ と開削面の 地山応力 $\left(\sigma_{\theta}\right)_{r=a}$ の算定を試みた。用いた数值は,

覆工外径 $a=100 \mathrm{~cm}$, 覆工内径 $b=90 \mathrm{~cm}$, コンク リート覆工の密度 $r_{l}=0.0025 \mathrm{~kg} / \mathrm{cm}^{3}$, 地山粘土の密度 $r_{s}=0.0016 \mathrm{~kg} / \mathrm{cm}^{3}$ (実験值), コンクリートの弾性係数 $E_{l}=2.1 \times 10^{5} \mathrm{~kg} / \mathrm{cm}^{2}$, 地山粘土の最終弾性係数 $E_{\infty}=$ $21.93 \mathrm{~kg} / \mathrm{cm}^{2}$ (実験值), コンクリートのポアソン比 $\nu_{l}$ $=0.167$, 粘土のポアソン比 $\nu=0.3$, 粘土の上限降伏值 $\tau_{u}=0.38 \mathrm{~kg} / \mathrm{cm}^{2}$ (実験值), 素掘り期間中のクリープ時間 $t_{c}=2 h=7200 \mathrm{sec}, \quad$ トンネル中以上の土かぶり $H=$ $600 \mathrm{~cm}$ 。

上記の $\gamma_{s}, E_{\infty}, \tau_{u}$ はある大阪沖積層粘土についての 実験值であるが，この粘土をクリープ試験および応力緩 和試験を行なって求めた time factor $\phi(t)$ および $\psi(t)$, $(t: \mathrm{sec})$ の実験值は;

$$
\begin{gathered}
\phi(t)=0.273+0.0774 \log _{10} t, \\
\psi(t)=2.580-0.2603 \log _{10} t
\end{gathered}
$$

これらの数值を式 $(65) \sim(68)$ に用い, 覆工構築後長 時間が経過し, 覆工土圧が最大に近くなったとしたとき
(計算では $\psi\left(t_{s}+t\right)=1$ のと)の土圧 $\left(\sigma_{r}\right)_{r=a},\left(\sigma_{\theta}\right)_{r=a}$ の值を電子計算機（京大 FACOM 230-60）を用いて求 め, 結果を図一5に示した。前述のように, この解析で

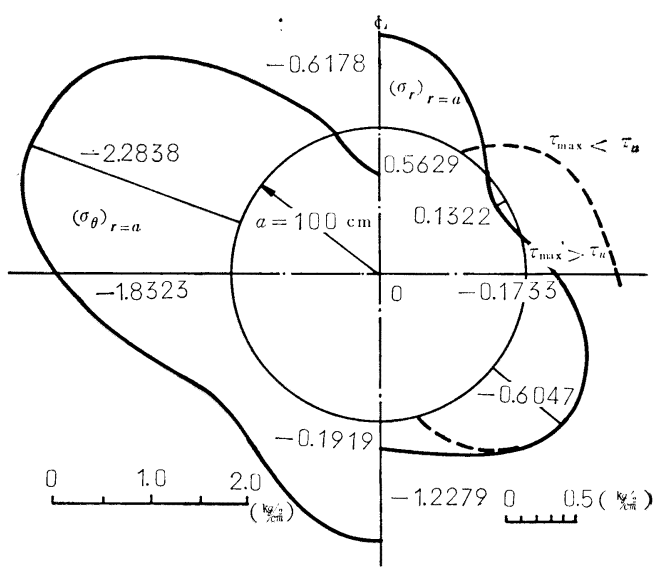

図一 5 開削面 $(\boldsymbol{r}=\boldsymbol{a})$ における地山の $\boldsymbol{\sigma}_{r}$ と $\boldsymbol{\sigma}_{\theta}$ の分 布 (単位 $\mathbf{k g} / \mathbf{c m}^{2}$ ) および $\tau_{\max }>\tau_{u}$ の領域

は地山に塑性域の生じることは前提としていないが，地 山の上限降伏值 $\tau_{u}$ を $0.38 \mathrm{~kg} / \mathrm{cm}^{2}$ とすると, 地山の主 せん断応力 $\tau_{\max }$ が $\tau_{u}$ を越す領域が 図一5 の点線内方 のように生じる。この領域は塑性域と同一ではないが, 近似的に塑性域とみるとこの領域の形は New Austrian Tunneling Method ${ }^{9}$ の中で仮説ながらこの工法のより どころの一つとしている塑性域 ${ }^{10)}$ の形状とかなりよく似 た形をとっている。

\section{5. あとがき}

現実のトンネルでは, 地山が十分強剛でないと, 開削 後覆工構築までの間, 地山開削面は時とともに変形を増 大する。このような開削面の流動変形が終結する以前に 覆工を構築すると, 地山の流動が抑制される結果, 覆工 には地山の応力緩和のための覆工土圧が生じ, 土圧は所 定の值に達するまでの期間, 時とともに増大する。

この報文は, 上述のような覆工土圧の時間依存性, 施 
工依存性を解明するため, 地山を均質粘土のような一様 な粘弾性体と想定し, 粘土のクリープ過程後の応力緩和 特性をレオロジ一的に解明するとともに, トンネルの施 工過程中の素掘り期間の存在, 坑内圧気圧の加除, 覆工 施工時期のほか覆工剛度, 地山の自重などの実際的な施 工条件を示す要素を計数的に導入して, 地山開削面のク リープ変形の推移や地山の応力緩和に基づく覆工土圧の 経時変化とその大きさを理論的に解析する一方法を示し たものである。

\section{参 考 文 献}

1）村山朔郎：粘性土中のトンネル土圧について, 第 18 回土 木学会年次学術講演会講演概要 III, pp. 57 58, 1963.

村山朔郎：トンネル土圧, 土木学会第 3 回トンネル工学 シンポジウム, pp. 10〜14, 1966.

村山朔郎・松岡 元 : 粘性土の 応力緩和によるトンネル 土圧, 土木学会論文報告集, No. 168, pp. 37〜43, 1969-9. 桜井春輔: 粘弾塑性地山内の円形トンネル覆工について, 土木学会論文報告集, No. 181, pp. 77〜89, 1970-9.

2) 村山朔郎：粘土のレオロジー特性の確率論的考察, 材料,
14 巻, 139 号, pp. 282 288, 1965-4.

3）村山朔郎：1）の第 1 および第 2 .

4) Hanns Schmid : Statische Probleme des Tunnel-und Druckstollenbaues und ihre gegenseitigen Beziehungen, Berlin Verlag von Julius Springer, 1926.

5）山口 昇: On the stresses around a horizontal circular hole in gravitating elastic solid, 土木学会誌, Vol. 15, No. 4, pp. 291 303, 1929-4.

6) N.I. Muskhelishvili : Some basic problems of the mathematical theory of elasticity, N.V. Noordhoff Groningen Holland, 4th corrected and augumented edition, pp. 205 208, 1954.

7) 谷本勉之助: 巻立円形隧道の応力分布, 土木学会誌 Vol. 23, No. 4, pp. 357 379, 1937-4.

8）小田英一：巻立棈円形トンネル周辺の忘力分布について, 土木学会論文集, No. 24, pp. 12 18, 1955-4.

9) L.V. Rabcewicz: The new Austrian tunneling method, Water Power, p. 456, 1964-11.

10) L.V. Rabcewicz und K. Sattler : Die neue Österreichische Tunnelbauweise, Bauingenieur, Ann. 40, Vol. 8, pp. 289 301, 1965.

(1972.1.28 - 受付) 